\title{
The Dawangou auxiliary GSSP (Xinjiang autonomous region, China) of the base of the Upper Ordovician Series: putting global chitinozoan biostratigraphy to the test
}

\author{
JAN HENNISSEN ${ }^{1,2, *}$, THIJS R. A. VANDENBROUCKE ${ }^{3}, \mathrm{XU}_{\mathrm{CHEN}^{4}, \mathrm{PENG} \mathrm{TANG}^{4} \text { \& JACQUES VERNIERS }}{ }^{1}$ \\ ${ }^{1}$ Palaeontology, Department of Geology, Ghent University Krijgslaan 281/S8 9000, Ghent, Belgium \\ ${ }^{2}$ Current address: Earth Sciences Centre, University of Toronto 22 Russell St, Toronto, Ontario M5S 3B1, Canada \\ ${ }^{3}$ FRE 3298 du CNRS: Géosystèmes, Université Lille 1 Avenue Paul Langevin, bâtiment SN5, 59655 Villeneuve d'Ascq cedex, France \\ ${ }^{4}$ State Key Laboratory of Palaeobiology and Stratigraphy, Nanjing Institute of Geology and Palaeontology, Chinese Academy of Sciences, \\ Nanjing 210008, PR China \\ ${ }^{*}$ Corresponding author (e-mail: hennissen@geology.utoronto.ca)
}

\begin{abstract}
The Dawangou section, an auxiliary Global Stratoype Section and Point (GSSP) for the base of the Upper Ordovician Series, was sampled for chitinozoans. The 32 samples taken from the black shales of the Saergan Formation, spanning the Pterograptus elegans, Didymograptus murchisoni and Nemagraptus gracilis graptolite biozones, yielded 6536 chitinozoan vesicles. In addition to a diverse endemic assemblage, species important for international correlation were recovered, which enables the subdivision of the Saergan Formation into two chitinozoan biozones, one subzone and one provisionally recognized biozone: the Baltoscandian Laufeldochitina striata Biozone and the Laurentian Lagenochitina sp. A (sensu Achab, 1984) (/Belonechitina hirsuta) Biozone, and the Belonechitina tuberculata Subzone are recognized based on the presence of the index species, while the Baltoscandian Laufeldochitina stentor Biozone is provisionally recognized on the presence of Laufeldochitina sp. A aff. striata sensu Grahn et al., 1996 which has a range confined to the latter biozone. One new chitinozoan species is described: Cyathochitina giraffa sp. nov. and two species were assigned to a different genus: Belonechitina tuberculata comb. nov. and Hercochitina seriespinosa comb. nov. J. Micropalaeontol. 29(2): 93-113, December 2010.
\end{abstract}

KEYWORDS: Ordovician, China, biostratigraphy, chitinozoans

\section{INTRODUCTION}

The chronostratigraphical boundaries in the International Stratigraphical Chart (ISC, Gradstein et al., 2004) are fixed using index events, such as first appearance datums (FADs) of key fossils. The stage boundaries have designated Global Stratoype Sections and Points (GSSPs). For the Ordovician, graptolites and conodonts are considered to be the most important biostratigraphical markers. However, chitinozoans can act as an important link between the former two fossil groups (Paris, 1996), as they occur in a wide range of marine rocks from the Early Ordovician to the latest Devonian (Miller, 1996; Paris, 1996; Paris \& Verniers, 2005).

The current chronostratigraphical scheme for the Ordovician uses graptolite and conodont biostratigraphy to define intrasystemic boundaries (Finney \& Bergström, 1986; Bergström et al., 1998; 2000; 2006; 2009). This paper aims to evaluate the chitinozoan biostratigraphy in the Dawangou section, which was of importance during the revision of the Ordovician chronostratigraphy and still is the auxiliary GSSP for the base of the Upper Ordovician Series (i.e. the Darriwilian-Sandbian boundary).

The section studied straddles the base of the Upper Ordovician Series (base of the Sandbian Stage), defined at the base of the Nemagraptus gracilis graptolite Biozone. This biozone has long been used as a stratigraphical marker and is widely recognized. Finney \& Bergström (1986) re-examined the biozone in key sections around the world. They concluded that further investigation was necessary to pinpoint the upper boundary of the biozone, but that its base is synchronous in all of these sections. However, this was contradicted by Bettley et al. (2001). Using graphic correlation methods, these authors stated that the FAD of $N$. gracilis is diachronous, first appearing in North
America and later in European sections, as result of a transgression. Finney \& Bergström (1986) proposed using the Berrybush Burn section in Scotland as the reference section for the $N$. gracilis Biozone, with the Fågelsång and Albany sections in Scania (Sweden) and New York (USA), respectively, as secondary reference sections. The Fågelsång and Calera (Alabama, USA) sections were proposed as the local reference sections for Europe and North America. A decade later, a number of sections were revised as candidates for the 'Golden Spike' of the base of the Upper Ordovician. The GSSP potential of three of these sections was evaluated by Bergström et al. (1998): the Fågelsång section, the Calera section and the Dawangou section (Xinjiang autonomous region, China). The Berrybush Burn section, previously mentioned as a favourite for the GSSP, was abandoned.

The Dawangou section was reviewed by Bergström et al. (1999). They concluded that this section provides a very good record of the base of the $N$. gracilis Biozone. The section itself is continuously exposed and has no structural complication. However, Bergström et al. (1999) reported some drawbacks to the section: firstly, it is stratigraphically condensed; secondly, very little of the $N$. gracilis Biozone is developed in the graptolite facies; thirdly, access to the section is difficult and expensive.

Bergström et al. (2000) published the final results of the world-wide assessment of the $N$. gracilis Biozone and the concurrent base of the Upper Ordovician. These authors recommended the Fågelsång section in Scania, Sweden as the GSSP of the base of the Upper Ordovician. Next to its stratigraphical advantages, it also is easily accessible. The latter makes it more acceptable as a GSSP than the Dawangou section, which is a few hours' drive and a one-hour walk away from the nearest town (Bergström et al., 1999). Nevertheless, the Dawangou and 


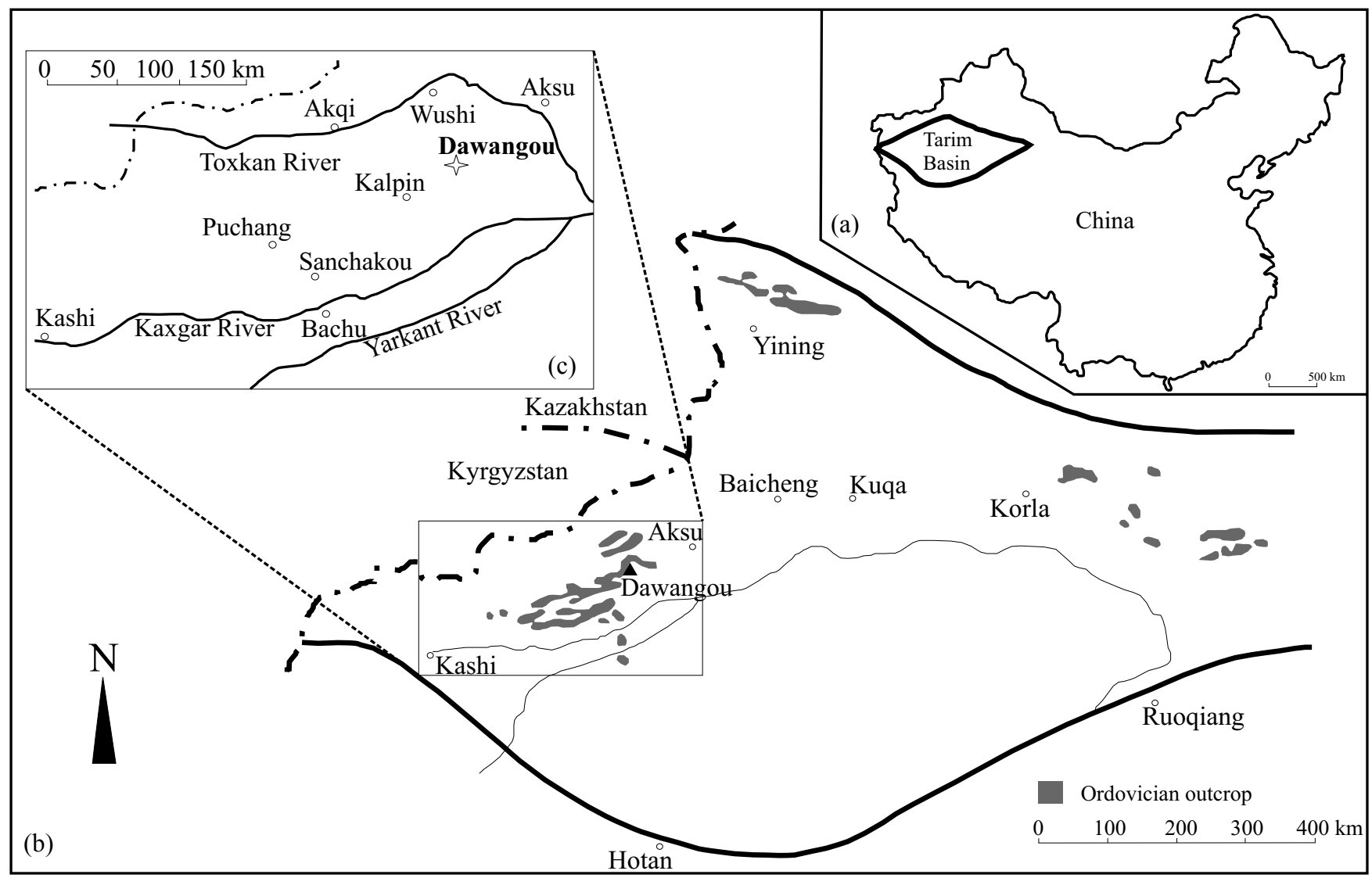

Fig. 1. Location of the Dawangou section: (a) the Tarim Basin in northwest China; (b) the Tarim Basin in detail, with the grouped Ordovician outcrops in the western part of the basin near the border with Kyrgyzstan; (c) location of the Dawangou section between the towns of Aksu and Kalpin and the Toxkan and Kaxgan rivers.

Calera sections were proposed as auxiliary GSSPs for the base of the Upper Ordovician as they can be closely correlated with the Fågelsång section (Bergström et al., 2000). We should mention here that whilst the Fågelsång section has been selected as the GSSP for the base of the Upper Ordovician Series, it may also have its drawbacks. The section contains a phosphorite bed at the base of the Lagenochitina dalbyensis chitinozoan Biozone, $1.4 \mathrm{~m}$ above the base of the Upper Ordovician Series, across which Vandenbroucke (2004) reported a conspicuous change in chitinozoan assemblages, possibly indicating a hiatus. The aim of the present study is to assess if we can correlate the auxiliary GSSP in Dawangou (China) to the GSSP in Fågelsång (Sweden) by means of chitinozoans. By doing so, we will explore the possibility of correlation between different palaeocontinents at the base of the Upper Ordovician Series.

\section{STUDY AREA}

The Dawangou section is situated in the Tarim Basin (Fig. 1), one of the largest endorheic basins of the planet in northwestern China and covers an area of $560000 \mathrm{~km}^{2}$. Tarim is situated in the hinterland of the Tibetan Plateau (Wang et al., 1992) and is bordered by the Tienshan Mountains to the north, the Kunlun Mountains in the southwest and the Aerjin Mountains in the southeast (Dameng et al., 2003). The Tarim Basin is the only basin in China with economic accumulations of oil and gas derived from both continental and marine source rocks (Jinggui et al., 2005). The recent increase in oil and natural gas exploration has resulted in a better understanding of the geology of the Tarim Basin (Zhou \& Chen, 1992; Li et al., 2006 and references therein).

The Dawangou section is a natural stream cut along an ephemeral creek in the Dawangou Gorge on the western slopes of the Tarim Plateau, about $15 \mathrm{~km}$ northwest of Yingan Village and about $75 \mathrm{~km}$ southwest of the town Aksu (Fig. 1c).

The section consists of a succession of limestones and shales reflecting turnovers between slope conditions and open basin environments (Zhou et al. 1992). The most important part of the section is the Saergan Formation, consisting of black shales intercalated with limestone banks formed during a gradual change towards open basin conditions in which graptolites thrive.

\section{EXISTING BIOSTRATIGRAPHY IN THE TARIM BASIN}

The samples used for this study were collected in the context of a large-scale revision of the biostratigraphy and geology of the Tarim Basin (see Zhou \& Chen, 1992). Zhou et al. (1992) provide a detailed list of samples also containing information about the chitinozoan content, but no detailed report of the chitinozoan assemblages is available. They report chitinozoans with long biostratigraphical ranges, less useful for correlation purposes, with Conochitina pirum and Rhabdochitina usitata as 
the most abundant specimens. Here, we assess whether a detailed examination of all the samples taken from the Saergan Formation could result in a much finer resolution suitable for zonal correlations with the schemes for Baltoscandia (Nõlvak \& Grahn, 1993), Laurentia (Achab, 1989), northern Gondwana (Paris, 1990) and British Avalonia (Vandenbroucke, 2008b).

Zhou et al. (1992) provide a detailed biozonation of the Saergan Formation based primarily on graptolite occurrences. The following biozones were described from the Saergan Formation in the Dawangou Section by Zhou et al. (1992), in ascending order (Fig. 2).

1. The Pterograptus elegans Biozone was recognized in the bottom part of the Dawangou section. This biozone is described as a part of the Didymograptus murchisoni Biozone in Webby et al. (2004) but, in the local Chinese scheme, it is a graptolite biozone outside the $D$. murchisoni Biozone. It ranges from sample NJ304 to NJ327, respectively, in Beds 11 and 12 .

2. The Didymograptus jiangxiensis Subzone is considered part of the D. murchisoni Biozone, above the P. elegans Subzone, in the Webby et al. (2004) scheme for China, as well as in the local Zhou et al. (1992) scheme, comprising samples NJ328-NJ356, from Beds 12 to 14.

3. Hustedograptus teretiusculus is described throughout the entire Saergan Formation, limiting its stratigraphical value. Zhou et al. (1992) used a tentative H. teretiusculus Subzone as part of a D. murchisoni Biozone until a more detailed subdivision becomes available. Chen et al. (2008) revised the interval NJ356-NJ364 (Bed 14) and assigned it to the local Dicellograptus vagus Subzone (Fig. 2).

4. The base of the Nemagraptus gracilis Biozone is accepted as the base of the Upper Ordovician (Bergström et al., 1998). Samples NJ365-NJ374 from Bed 14 from the Saergan Formation fall in the range of this biozone and thus are attributed an Upper Ordovician age.

\section{CHITINOZOAN SAMPLES}

The samples used in this study (Table 1) are catalogued using the same bed numbers as cited above (Fig. 2) and we refer to Zhou et al. (1992) for a full description of the beds and their fossil content. The samples were treated according to standard palynological preparation techniques (for detailed description, see Paris, 1981). The weight of the treated rock fragments varied between $6.2 \mathrm{~g}$ and $15.8 \mathrm{~g}$ per sample. A total of 6536 chitinozoans were extracted and most were studied with the scanning electron microscope (JEOL 6400). Some specimens could be identified using an optical microscope with stereoscopic vision at a magnification of $\times 500$.

\section{CHITINOZOAN RESULTS FROM THE DAWANGOU SECTION}

The results of the present study are shown in Table 1. In total, $341.8 \mathrm{~g}$ of samples was dissolved from the Saergan Formation. Four long-ranging species were described: Cyathochitina campanulaeformis, Cyathochitina giraffa sp. nov., Belonechitina micracantha and Lagenochitina pirum.

More than half of all the recovered specimens are identified as C. campanulaeformis (3762 throughout the Saergan Forma- tion). There is a clear dominance of $C$. campanulaeformis, especially in the lower part (with 442 specimens, $82 \%$ in sample NJ331) and in the middle (with 694 vesicles, 90\% in sample NJ344 and 803 or $92 \%$ in NJ345) of the section.

In the studied interval, a distinctive assemblage of Belonechitina specimens is present (628 specimens in the B. micracantha group, $9.6 \%$ of the total amount of chitinozoans) and exceptionally high numbers of Angochitina capillata in sample NJ347 (134 specimens or $61 \%$ ) and Hercochitina cf. spinetum in sample NJ355 (200 specimens or $68 \%$ ).

Abundances typically vary between 5 chitinozoans per gram and 25 chitinozoans per gram with some peaks in samples NJ344 and NJ345, containing 80 and 73 chitinozoans per gram, respectively.

In the Saergan Formation, the chitinozoans are well preserved, which is reflected in the relatively high abundances (Table 1) and the preservation of detail of some wall ultrastructures, such as the striations on Laufeldochitina striata (Pl. 1, fig. 7a) and wall ultrastructures on certain specimens of C. campanulaeformis (Pl. 4, figs 6a, 7a). The taxonomy of the retrieved species is explained below, in the systematic description.

\section{CHITINOZOAN BIOZONES IN THE DAWANGOU SECTION}

In this study 41 species and species groups were recognized from 32 samples. The ranges of 29 species are given in Figure 2, five of which are readily applicable in international correlation: Lagenochitina sp. A sensu Achab, 1984 (P1. 4, figs 1-4, 3a, 4a), Laufeldochitina striata (P1. 1, figs 5-7, 6a, 7a), Laufeldochitina sp. A aff. striata sensu Grahn et al., 1996 (P1. 1, figs 3, 4, 3a, 4a), Belonechitina tuberculata (P1. 1, figs 1, 2, 1a, 2a) and Lagenochitina sp. A aff. capax sensu Grahn et al., 1996. These are either index species for chitinozoan biozones recognized on other palaeocontinents, or very distinctive species that occur in certain, well-defined intervals.

B. tuberculata and L. sp. A aff. capax sensu Grahn et al., 1996 have a significant correlative value and were originally defined in the Baltoscandian area. They serve as type species for chitinozoan biozones in the Floian, Dapingian and Darriwilian stages. Laufeldochitina striata (range: NJ349-NJ355 and possibly one specimen in sample NJ367) is the type species for the L. striata Biozone defined by Nõlvak \& Grahn (1993). This biozone contains a subzone with type species $B$. tuberculata (Nõlvak \& Grahn, 1993), here recovered from samples NJ352 and NJ355. The different chitinozoan biozones recognized in the Saergan Formation of the Dawangou section are shown in Figure 2 and are discussed below in ascending order.

\section{Laufeldochitina striata Biozone (Nõlvak \& Grahn, 1993)}

Definition. This Baltoscandian biozone was defined by Nõlvak \& Grahn (1993). It corresponds to the total range of its type species Laufeldochitina striata (Eisenack, 1937) and its type interval and locality is situated in Västergötland, south-central Sweden in the Gullhögen and lower Ryd formations in the Uhaku Stage (Nõlvak \& Grahn, 1993).

Characteristic chitinozoans in the Dawangou section. Belonechitina sp. 2 appears together with L. striata. Lagenochitina aff. 


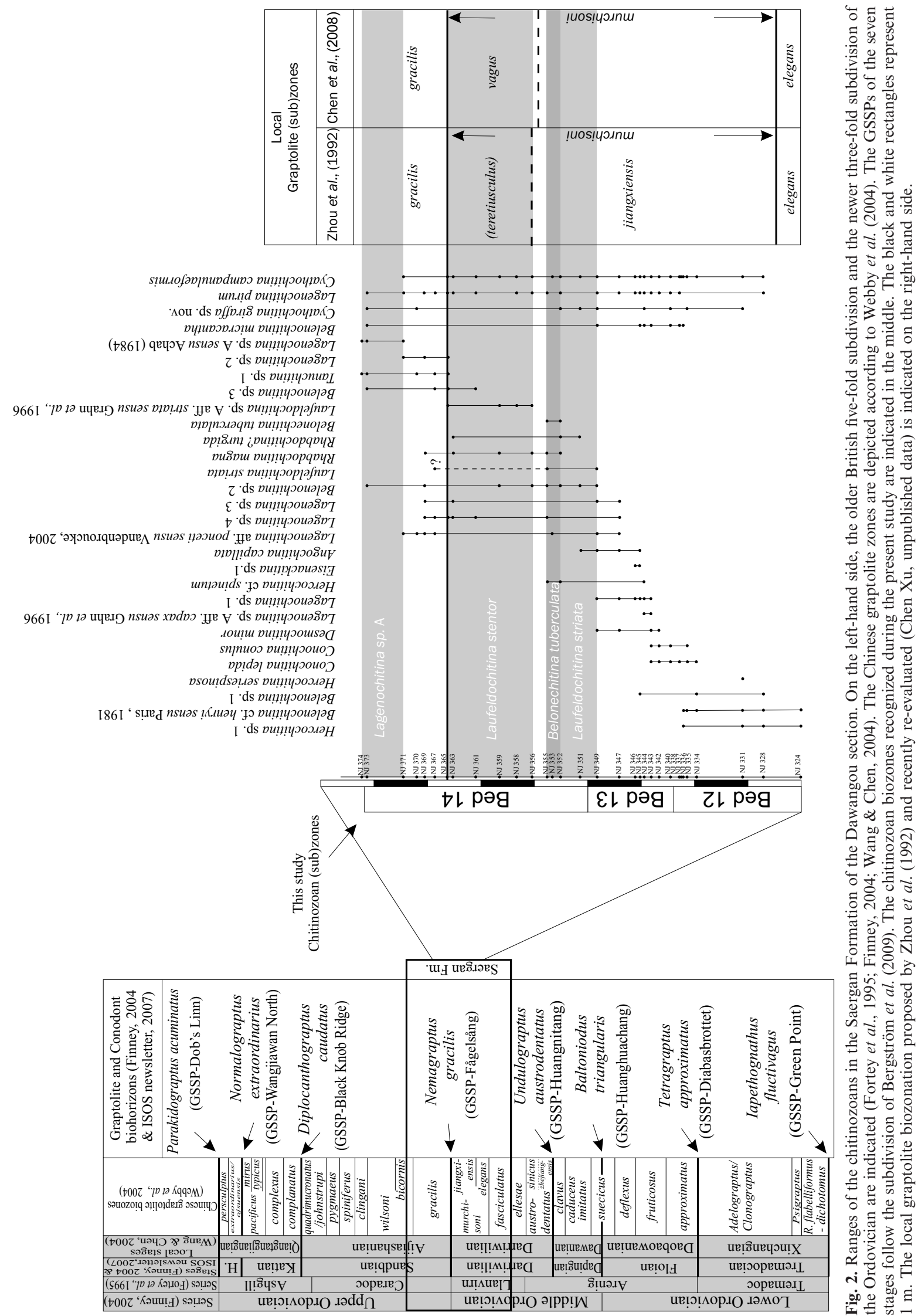


Putting global chitinozoan biostratigraphy to the test: China

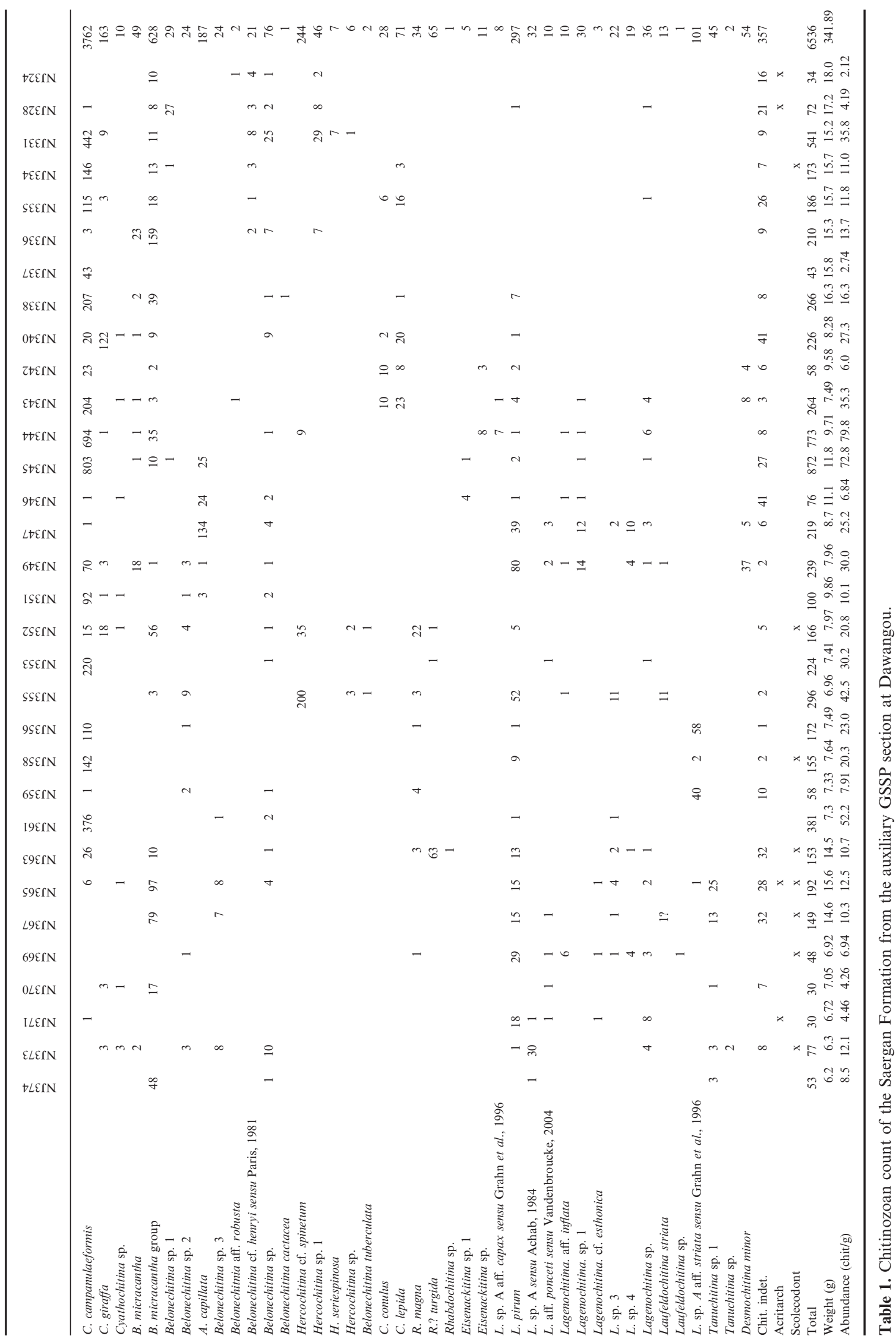




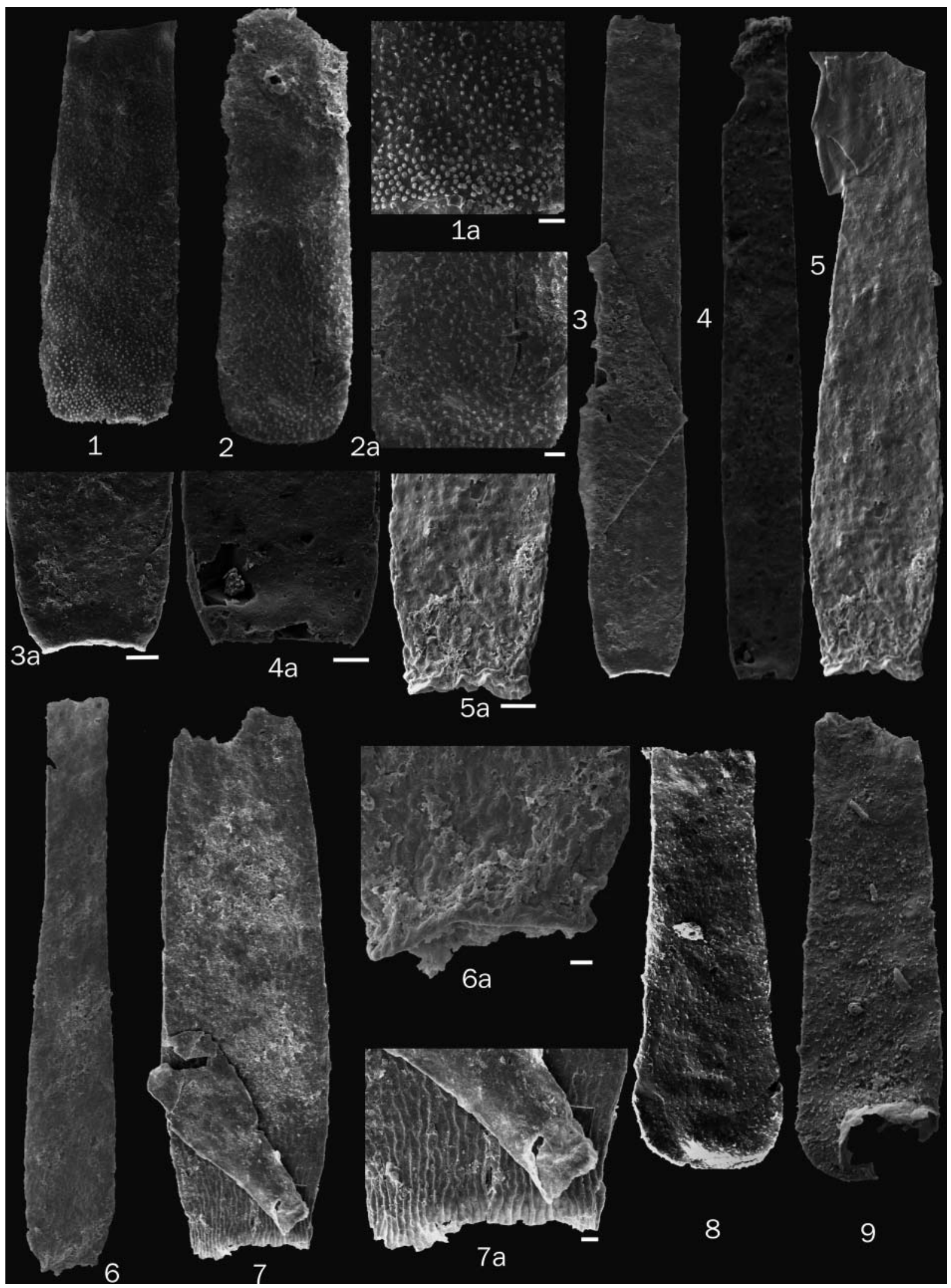


ponceti sensu Vandenbroucke, 2004 appears lower in the section (FAD at NJ347) and is present in the whole of the L. striata Biozone. Hercochitina cf. spinetum appears lower (sample NJ347) and its highest occurrence (HO) coincides with the HO of L. striata. Angochitina capillata emerges lower than L. striata but disappears within the biozone. The HOs of Lagenochitina sp. 1 and Desmochitina minor concur with the lowest occurrence (LO) of L. striata. Belonechitina tuberculata appears in the top section of the biozone and its $\mathrm{HO}$ coincides with the $\mathrm{HO}$ of $L$. striata. B. tuberculata is the type species of a subzone in the L. striata Biozone (Nõlvak \& Grahn, 1993). The long-ranging species Cyathochitina giraffa sp. nov., Cyathochitina campanulaeformis and Lagenochitina pirum were recovered alongside L. striata.

Discussion. Nõlvak \& Grahn (1993) recognized three subbiozones within this biozone: the Cyathochitina sebyensis, the Conochitina clavaherculi and $B$ tuberculata sub-biozones. Neither Cyathochitina sebyensis nor Conochitina clavaherculi were recovered from the Saergan Formation. Belonechitina tuberculata is described in the top part of the biozone both in the Dawangou section and the type locality in Västergötland. Nõlvak \& Grahn (1993) listed Belonechitina crinata, Belonechitina pellifera, Pterochitina retracta, Lagenochitina tumida s.1. (Männil, 1986), Sagenochitina sp. (=Baltochitina nolvaki Paris et al., 1999) and Tanuchitina tallinensis, and as concurrent species in the L. striata Biozone. The only other specimen both sections have in common, besides L. striata and B. tuberculata, is C.campanulaeformis.

We recovered one additional specimen that may be identified as L. striata higher in the section, i.e. in sample NJ369, but it lacked the distinctive ridges on the carina. The carina in this specimen is longer than in the case of Laufeldochitina sp. A aff. striata sensu Grahn et al., 1996, but poor preservation hampers definitive identification. For the sake of completeness it was added in the stratigraphical range chart as a questionable occurrence (Fig. 2) but, because of its poor preservation, it was excluded from the actual L. striata Biozone.

\section{Stratigraphic range in the Dawangou section. NJ349-NJ355}

\section{Belonechitina tuberculata Subzone (Nõlvak \& Grahn, 1993)}

Definition. This Baltoscandian Sub-biozone of the Laufeldochitina striata Biozone was defined by Nõlvak \& Grahn (1993) and corresponds to the partial range biozone of Belonechitina tuberculata between the $\mathrm{HO}$ of Conochitina clavaherculi and the LO of Eisenackitina rhenana. Its type locality is situated in the allochthon at Halde bei Metzingen in Württemberg, Germany. Nõlvak \& Grahn (1993) originally described this sub-biozone as the Conochitina tuberculata Sub-biozone, but - following the chitinozoan classification scheme by Paris et al. (1999) - we suggest here that it is preferable to include the type species in the genus Belonechitina (see Systematic Description section).

Characteristic chitinozoans in the Dawangou section. L. striata is the most important species that co-exists with $B$. tuberculata. Additional species include Belonechitina sp. 2 and Lagenochitina aff. ponceti sensu Vandenbroucke, 2004, mentioned above. Rhabdochitina magna appears in the same samples as B. tuberculata (NJ352 and NJ355) but has a longer range. The HOs of B. tuberculata and Hercochitina cf. spinetum coincide. Three of the four long-ranging species cited above (see L. striata Biozone) occur in the $C$. tuberculata Sub-biozone, and the range of Belonechitina micracantha spans the B. tuberculata Sub-biozone, though no occurrences are reported here.

Discussion. Because we found neither $C$. clavaherculi nor $E$. rhenana, both boundaries of the $B$. tuberculata Sub-biozone are ill-constrained here. L. striata is the only species mentioned by Nõlvak \& Grahn (1993) to overlap in range with C. tuberculata. Because of the absence of Laufeldochitina stentor (the type species of the Biozone above the L. striata Biozone), it is difficult to pinpoint the stratigraphical position of the L. striata Biozone in relation to the Baltoscandian biozonation. Therefore, the value of the $B$. tuberculata Sub-biozone should not be underestimated because it enhances the precision of our correlation of the L. striata Biozone with other palaeocontinents as it occurs at the very top of the biozone.

\section{Stratigraphic range in the Dawangou section. NJ352-NJ355}

\section{Laufeldochitina stentor Biozone (Nõlvak \& Grahn, 1993)}

Definition. This biozone corresponds to the total range of Laufeldochitina stentor. It was defined by Nõlvak \& Grahn (1993) in the upper Uhaku and lower Dalby formations of Västergötland, south-central Sweden.

Characteristic chitinozoans in the Dawangou section. The most important chitinozoan species retrieved is Laufeldochitina sp. A aff. striata sensu Grahn et al., 1996. This species is reported to have an overlapping range with L. stentor (Grahn et al., 1996), in the middle part of the L. stentor Biozone. The LO of Lagenochitina sp. 2 coincides with the $\mathrm{HO}$ of $L$. sp. A aff. striata sensu Grahn et al., 1996. Belonechitina sp. 3 appears in the upper part of the interval. Rhabdochitina? turgida disappears just below the top of the biozone (in sample NJ363). Other species with a largely concurrent range are: Lagenochitina aff. ponceti sensu Vandenbroucke, 2004; Rhabdochitina magna; Lagenochitina sp. 3; Lagenochitina sp. 3; and the long-ranging species Lagenochitina pirum and Cyathochitina campanulaeformis.

\section{Explanation of Plate 1.}

figs 1, 2. Belonechitina tuberculata (scale bars $10 \mu \mathrm{m}$ ): 1, $310 \times 120$ incomplete specimen (sample NJ352) - 1a, detail of 1; 2, $350 \times 110$ incomplete specimen (sample NJ355) - 2a, detail of 2. figs 3, 4. Laufeldochitina sp. A aff. striata Grahn et al., 1996 (scale bars $25 \mu \mathrm{m}): 3,910 \times 140 \times 100$ (sample NJ356) - 3a, detail of 3; 4, $1175 \times 145 \times 100($ sample NJ356) - 4a, detail of 4. figs 5-7. Laufeldochitina striata: 5, $565 \times 120 \times 75($ sample NJ367) - 5a, detail of 5, scale bar $25 \mu \mathrm{m} ; \mathbf{6}, 985 \times 140 \times 100$ (sample NJ355) - 6a, detail of 6, scale bar $10 \mu \mathrm{m} ; \mathbf{7 ,} 650 \times 210$ incomplete specimen with chitinozoan debris on top (sample NJ349) - 7a, detail of 7, scale bar $25 \mu \mathrm{m}$. figs 8, 9. Belonechitina cf. henryi: $8,315 \times 100 \times 80$ (sample NJ324); 9, $330 \times 100 \times 80($ sample NJ324). 


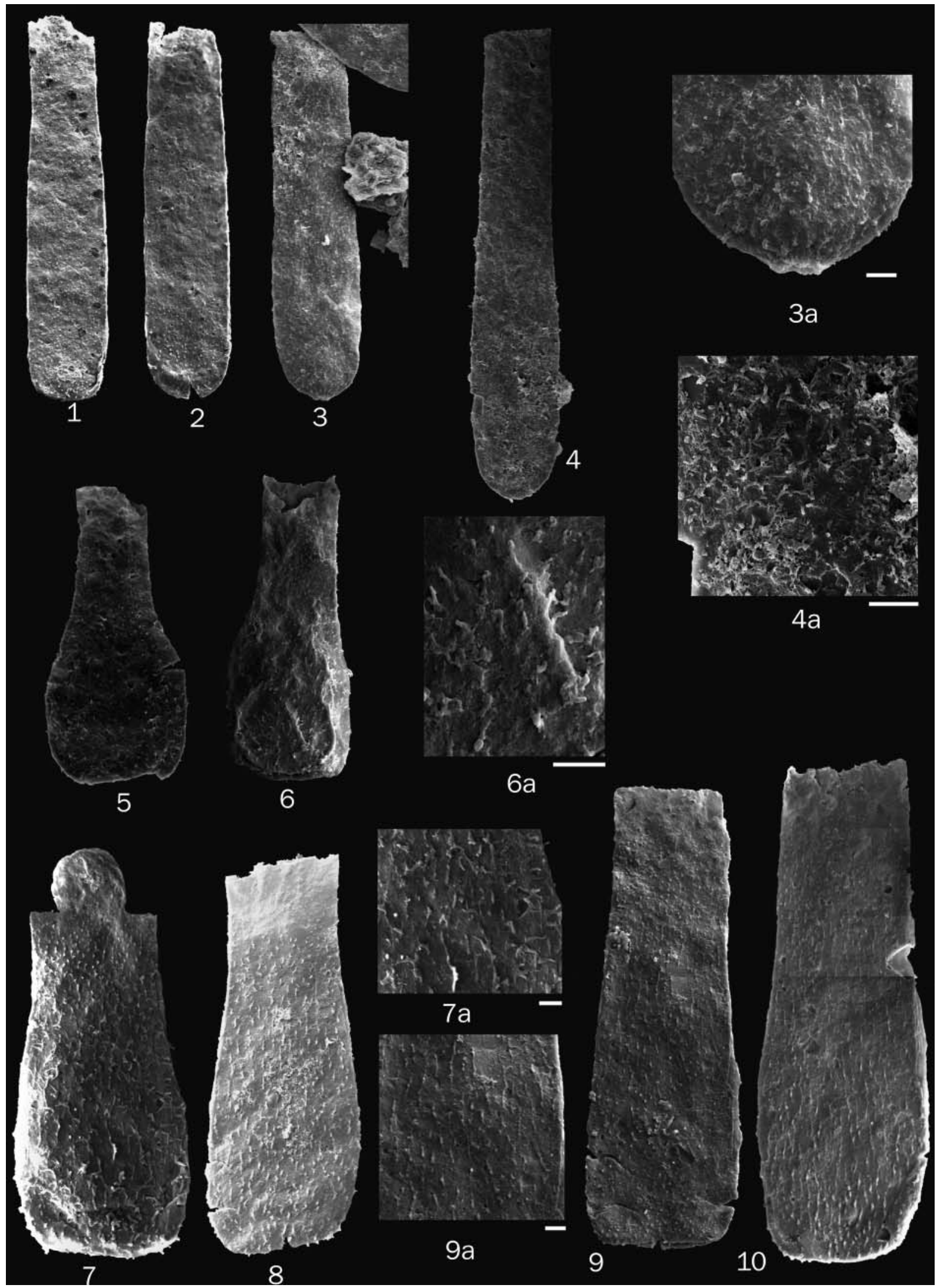


Discussion. Because of the absence of the index species of the biozone proposed for this interval in the Saergan Formation, the biozonal attribution remains uncertain. However, we have good circumstantial evidence to attribute this part of the Dawangou section to the L. stentor Biozone. L. sp. A aff. striata sensu Grahn et al., 1996 is reported only within the range of L. stentor. The range of the former species is placed in the middle part of the biozone where the abundance of $L$. stentor seemed to wane (Grahn et al., 1996). Männil (1986) reported an identical species that he identified as Laufeldochitina cf. striata in the same interval (Nõlvak \& Grahn, 1993 and references therein). Grahn et al. (1996) suggested synonymizing Männil's species with $L$. sp. A aff. striata sensu Grahn et al., 1996.

\section{Stratigraphic range in the Dawangou section. NJ356-NJ365}

\section{Lagenochitina sp. A sensu Achab (1986)/Belonechitina hirsuta Biozone (Achab, 1989)}

Definition. The Laurentian Lagenochitina sp. A sensu Achab, 1986/Belonechitina hirsuta Biozone was defined by the total range of the two type species. At the type locality, the Mictaw outcrop of the Gaspe Peninsula in Canada, both specimens appear at the same stratigraphical level. The upper limit of this biozone is defined by the $\mathrm{HO}$ of $B$. hirsuta, because it has a slightly longer range than L. sp. A sensu Achab, 1986.

Characteristic chitinozoans in the Dawangou section. The range of L. sp. A sensu Achab (1986) coincides partially with the ranges of Tanuchitina sp. 1, Belonechitina sp. 2 and Belonechitina sp. 3. Lagenochitina sp. 2 and Lagenochitina aff. ponceti sensu Vandenbroucke, 2004 have their HO at the very base of the proposed biozone. Belonechitina micracantha, Lagenochitina pirum and Cyathochitina giraffa sp. nov. are other commonly occurring co-existent species.

Discussion. The presence of L. sp. A sensu Achab, 1986 is a conclusive element to identify the discussed biozone in the Dawangou section. However, it should be mentioned that $B$. hirsuta was not recovered. A closely related specimen, B. sp. 3 shows great similarities with $B$. hirsuta, but the ornamentation is sparser (see systematic descriptions and Pl. 2, figs 5, 6). B. sp. 3 appears lower than $L$. sp. A sensu Achab, 1986 and its HO is just beneath the $\mathrm{HO}$ of the latter. L. pirum overlaps in range with $L$. sp. A sensu Achab, 1986 both in the Canadian and Dawangou sections.

Stratigraphic range in the Dawangou section. NJ371-NJ374

\section{GLOBAL CORRELATIONS}

The correlation chart for this study is shown in Figure 3; it illustrates a number of common species and links between the
Laurentian and Baltoscandian palaeocontinents and our study area. The position of the Tarim Basin at the base of the Upper Ordovician as a separate entity around $15^{\circ} \mathrm{N}$ is at similar palaeolatitudes as Baltica and Laurentia (Cocks \& Torsvik, 2002). Thus, a similarity in faunal associations between Baltica and Laurentia on the one hand and continental terranes roughly at similar palaeolatitudes, like Tarim, on the other hand, seems plausible (cf. Vandenbroucke et al., 2010).

Using the graptolite biostratigraphy in Dawangou and Baltoscandia as a reference framework, the Laufeldochitina striata Biozone appears in younger strata in the Dawangou section than it does in the Baltoscandian sections. The base of the L. striata Biozone in the Dawangou section appears in the Didymograptus murchisoni graptolite Biozone, while it is already present in the Pterograptus elegans graptolite Biozone in Baltoscandia. Similarly, when considering the position of the base of the Lagenochitina sp. A/Belonechitina hirsuta Biozone, its index species appears well above the base of the Nemagraptus gracilis graptolite Biozone in the present study, but is already present in the upper part of the Middle Ordovician in the Laurentian sections described by Achab (1986, 1989), where it is typical of strata assigned to the Heustedograptus teretiusculus and $N$. gracilis Biozones.

For the Laufeldochitina stentor chitinozoan Biozone it is somewhat complicated to evaluate the position of the base of biozones on both continents since we did not observe the index fossil and because the specimens described here were indicative of the middle part of the biozone only, leaving the interval somewhat ill-constrained. Taken at face value, the base of the $L$. stentor chitinozoan Biozone in the Dawangou section is situated at the level of the D. murchisoni graptolite Biozone (Zhou et al., 1992; Chen $\mathrm{Xu}$, pers. comm.) and slightly below the top of the Pygodus serra conodont Biozone. In Baltoscandia, the level at the base of the L. stentor chitinozoan Biozone more or less coincides with the top of the P. serra conodont Biozone, hence it is possibly slightly higher in the stratigraphy. In the Fågelsång GSSP, the L. stentor chitinozoan Biozone straddles the base of the Upper Ordovician Series, or the base of the Nemagraptus gracilis Biozone (Bergström et al., 2000; Vandenbroucke, 2004); Laufeldochitina sp. A aff. striata sensu Grahn et al., 1996, used herein as an index fossil, has been reported from below and above the GSSP (Grahn, in Bergström et al., 2000), while in Dawangou it is restricted to the Dicellograptus vagus graptolite Biozone.

Vandenbroucke (2004) proposed the base of the Eisenackitina rhenana Subzone as a proxy for the base of the Upper Ordovician Series in the Fågelsång GSSP; the index species of this subzone was not observed in this study of the Saergan Formation of the Dawangou section. Currently reported from Baltica (Nolvak \& Grahn, 1993 and references therein), Gondwana (Paris, 1981) and Avalonia (Eisenack, 1939; Vandenbroucke et al., 2009), this widespread species nevertheless deserves further investigation within this context.

\section{Explanation of Plate 2.}

figs 1, 2. Belonechitina sp. 1: 1, $480 \times 130 \times 130$ (sample NJ328); 2, $540 \times 110 \times 110$ (sample NJ328). figs 3, 4. Belonechitina sp. 2 (scale bars $10 \mu \mathrm{m}): \mathbf{3}, 390 \times 100 \times 85$ (sample NJ355) - 3a, detail of 3; 4, 610 × $110 \times 85$ (sample NJ355) - 4a, detail of 4. figs 5, 6. Belonechitina sp. 3: $\mathbf{5}, 200 \times 100 \times 50($ sample NJ373); 6, $210 \times 90 \times 55$ (sample NJ373) - 6a, detail of 6 (scale bar $10 \mu \mathrm{m})$. figs 7, 8. Hercochitina seriespinosa: 7, $280 \times 140 \times 100$ (sample NJ331) - 7a, detail of 7 (scale bar $10 \mu \mathrm{m}) ; \mathbf{8}, 275 \times 115 \times 80$ (sample NJ331). figs 9, 10. Hercochitina sp. 1: $\mathbf{9}, 350 \times 120 \times 90($ sample NJ328) $-\mathbf{9 a}$, detail of $9($ scale bar $10 \mu \mathrm{m}) ; \mathbf{1 0}, 310 \times 100 \times 80($ sample NJ331). 
Nõlvak \& Grahn (1993)

\section{Baltoscandia}

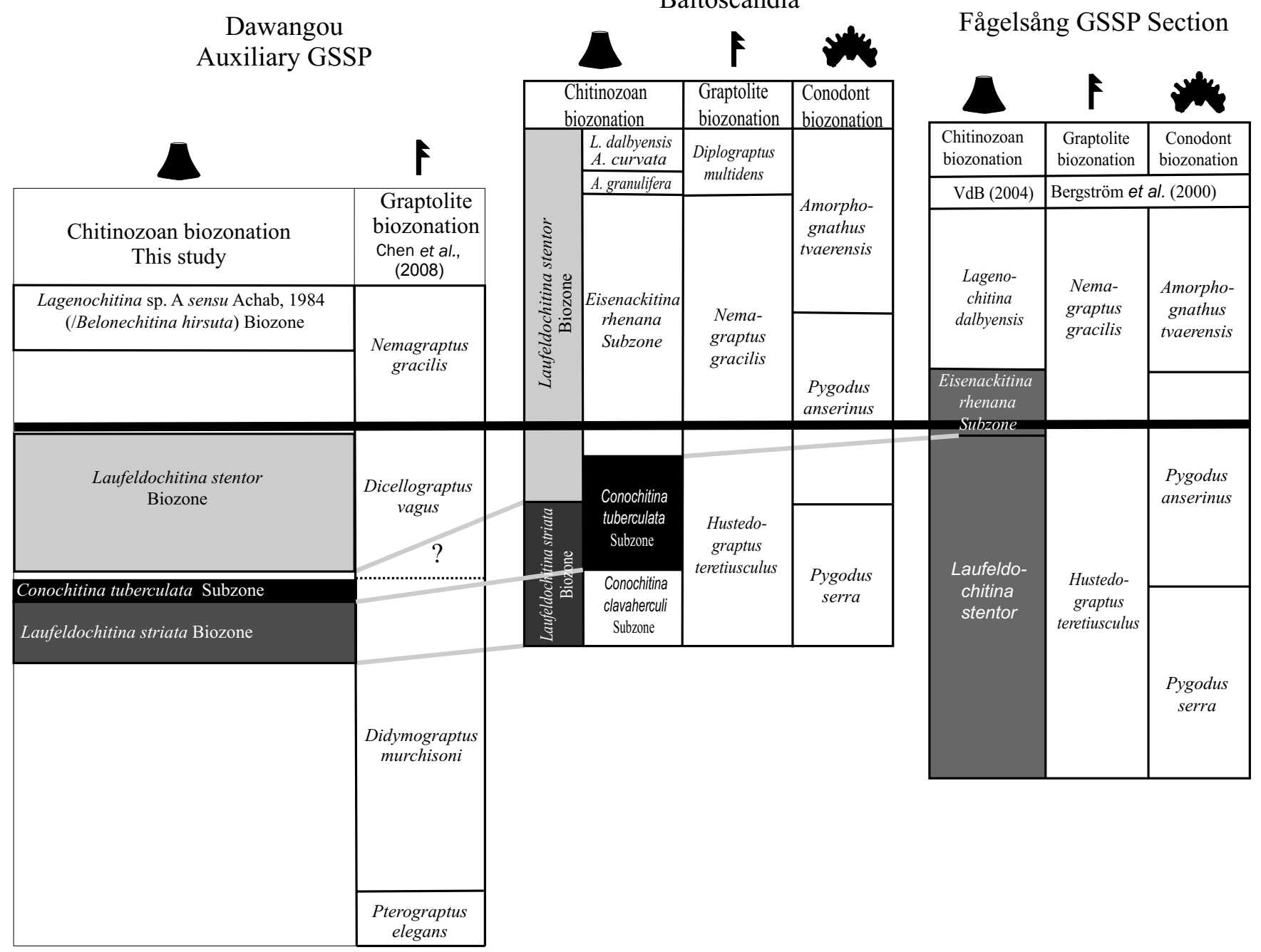

Fig. 3. Correlation between the Dawangou auxiliary GSSP, based on the data of the present study, the Baltoscandian palaeocontinent, according to Nõlvak \& Grahn (1993) and the Fågelsång GSSP for the base of the Upper Ordovician (Vandenbroucke, 2004). The thick line in the middle represents the base of the Nemagraptus gracilis Sub-biozone concurring with the base of the Upper Ordovician Series.

\section{SYSTEMATIC DESCRIPTIONS}

Open nomenclature is used following the recommendations by Bengtson (1988). Chitinozoan dimensions are all in micrometres and are given for the total length (L), maximal chamber diameter $(\mathrm{Dp})$ and the diameter of the oral tube (Dc), following Paris (1981). No correction for flattening was applied. All specimens are housed at the Research Unit Palaeontology, Ghent University, Belgium, with the exception of the holotype of Cyathochitina giraffa sp. nov., which is in the museum collections of the Royal Belgian Institute of Natural Sciences (RBINS; Vautierstraat 29, Brussels, Belgium).

Incertae Sedis Group Eisenack, 1931

Order Prosomatifera Eisenack, 1972

Family Conochitinidae Eisenack, 1972, emend. Paris, 1981

Subfamily Conochitininae Paris, 1981

Genus Laufeldochitina Paris, 1981

\section{Laufeldochitina sp. A aff. striata (Eisenack, 1937) sensu} Grahn et al., 1996

(P1. 1, figs 3, 4, 3a, 4a)

Description. Laufeldochitina species with an average vesicle length of $809.3 \mu \mathrm{m}$ (Table 2), a subcylindrical body and a cylindrical neck. The basal part is encircled by a small complete carina. The vesicle is smooth, but near the base some wrinkles are visible in some cases.

Stratigraphic range in the Dawangou section. NJ356-NJ358 (Dicellograptus vagus graptolite Subzone) and NJ365 (Nemagraptus gracilis graptolite Biozone).

Remarks. In the holotype description of Laufeldochitina striata, Eisenack (1937) mentions transverse striations in the middle part of the vesicle. These were not observed in any of the specimens in our study. Most of the specimens are in open nomenclature 


\begin{tabular}{lccrccr}
\hline $\begin{array}{l}\text { Laufeldochitina } \\
\text { sp. A aff. striata }\end{array}$ & $\begin{array}{c}\mathrm{L} \\
(\mu \mathrm{m})\end{array}$ & $\begin{array}{c}\mathrm{Dp} \\
(\mu \mathrm{m})\end{array}$ & $\begin{array}{c}\mathrm{Dc} \\
(\mu \mathrm{m})\end{array}$ & $\mathrm{Dp} / \mathrm{Dc}$ & $\mathrm{L} / \mathrm{Dp}$ & $\mathrm{L} / \mathrm{Dc}$ \\
\hline Average & 809.3 & 126.0 & 99.2 & 1.27 & 6.48 & 8.27 \\
Max & 1175.0 & 150.0 & 120.0 & 1.50 & 9.00 & 12.00 \\
Min & 400.0 & 95.0 & 75.0 & 1.00 & 3.33 & 4.00 \\
\hline
\end{tabular}

Dimensions based on 26 complete vesicles of Laufeldochitina sp. A aff. striata sensu Grahn et al., 1996.

Table 2. Dimensions of Laufeldochitina sp. A aff. striata sensu Grahn et al., 1996.

\begin{tabular}{lccrrrr}
\hline $\begin{array}{l}\text { Laufeldochitina } \\
\text { striata }\end{array}$ & $\begin{array}{c}\mathrm{L} \\
(\mu \mathrm{m})\end{array}$ & $\begin{array}{c}\mathrm{Dp} \\
(\mu \mathrm{m})\end{array}$ & $\begin{array}{c}\mathrm{Dc} \\
(\mu \mathrm{m})\end{array}$ & $\mathrm{Dp} / \mathrm{Dc}$ & $\mathrm{L} / \mathrm{Dp}$ & $\mathrm{L} / \mathrm{Dc}$ \\
\hline Average & 706.5 & 158.0 & 96.0 & 1.67 & 4.66 & 7.34 \\
Max & 985.0 & 225.0 & 110.0 & 2.65 & 6.79 & 9.85 \\
Min & 460.0 & 110.0 & 80.0 & 1.36 & 2.19 & 5.11 \\
\hline
\end{tabular}

Dimensions of 10 complete specimens of Laufeldochitina striata.

Table 3. Dimensions of Laufeldochitina striata.

because of the poor state of preservation. Many of the specimens have an almost smooth vesicle wall. Some specimens show the cylindrical chamber shape characteristic of the genus Tanuchitina. Nevertheless, because of the - on average - more claviform silhouette of the vesicle, we included the species in the genus Laufeldochitina. The description of Grahn et al. (1996) mentions a smooth wall and striations at the base of the vesicle. This description matches the observations of the Dawangou specimens.

\section{Laufeldochitina striata (Eisenack, 1937)}

(Pl. 1, figs 5-7, 5a, 6a, 7a)

Description. Long chitinozoan species (average length is 706.5 $\mu \mathrm{m}$, Table 3) with an extensive carina, and clear striations and wrinkles just above and on the carina (Pl. 1, figs 5, 6a, 7a). Some transversal banding was observed on one specimen just above the base (Pl. 1, fig. 5) and the longitudinal ridges, characteristic of Laufeldochitina striata, are clearly depicted in Plate 1 (fig. 7a).

Stratigraphic range in the Dawangou section. NJ349 and NJ355 (Didymograptus murchisoni graptolite Subzone).

Remarks. The dimensions of the recovered specimens fall within the range given by Eisenack (1937). The striations described by Eisenack (1937), and which we mentioned above in the description from Laufeldochitina aff. striata sensu Grahn et al., 1996, were not always shown in the vesicles picked. The furrows and wrinkles of the Dawangou specimens correspond well to the specimens described by Grahn (1981a). L. striata is close in shape to Tanuchitina sp. 1 but has a much longer and ornamented carina.

One specimen appears higher in the stratigraphy (in sample NJ363). This specimen belongs to the genus Laufeldochitina, but it lacks the distinct ridges on its carina. The carina is longer than the ones measured on L. sp. A aff. striata sensu Grahn et al.,

\begin{tabular}{lccrccc}
\hline $\begin{array}{l}\text { Belonechitina } \text { cf. } \\
\text { henryi }\end{array}$ & $\begin{array}{c}\mathrm{L} \\
(\mu \mathrm{m})\end{array}$ & $\begin{array}{c}\mathrm{Dp} \\
(\mu \mathrm{m})\end{array}$ & $\begin{array}{c}\text { Dc } \\
(\mu \mathrm{m})\end{array}$ & Dp/Dc & L/Dp & L/Dc \\
\hline Average & 314.3 & 108.6 & 82.5 & 1.31 & 2.92 & 3.82 \\
Max & 400.0 & 140.0 & 100.0 & 1.44 & 3.64 & 4.67 \\
Min & 250.0 & 100.0 & 75.0 & 1.22 & 2.27 & 3.13 \\
\hline
\end{tabular}

Measurements on 14 complete vesicles of Belonechitina cf. henryi.

Table 4. Dimensions of Belonechitina cf. henryi.

1996 specimens from this study. This particular specimen has intermediate characteristics between the latter and L. striata. This is why it is left in open nomenclature, but included in the biostratigraphical framework, occurring above the L. striata Biozone.

Subfamily Belonechitininae Paris, 1981

Genus Belonechitina Jansonius, 1964

Belonechitina cf. henryi Paris, 1981

(Pl. 1, figs 8, 9)

Description. The vesicle, with an average chamber length of $314.3 \mu \mathrm{m}$ (Table 4), has an inconspicuous flexure. The vesicle wall is covered with spines. The shape of the chamber is near cylindrical. The silhouette is conical and, in some cases, shows a conical mucron. This species is characterized by its ornamentation. The spines often align parallel to the vertical axis of the vesicle, although it does not show the same degree of alignment that can be found on the walls of species of the genus Hercochitina. The spines are densely implanted on the test but are sparser near the oral pole, or even disappear completely in some specimens.

Stratigraphic range in the Dawangou section. NJ324 (Pterograptus elegans graptolite Biozone)-NJ336 (Didymograptus murchisoni graptolite Subzone).

Remarks. The overall shape of the vesicle is close to that of Belonechitina henryi. The spines of Belonechitina cf. henryi are clearly more complex than the spines of B. micracantha: the spines have elongated, triangular bases ending in a slender, curved spine, while $B$. micracantha bears spines that are neither elongated nor multi-rooted. Although the chamber shape is sometimes close to that of Belonechitina robusta, no typical lambda-spines were encountered. $B$. henryi has about the same overall silhouette as $B$. cf. henryi, but has never been reported to have spines which line up along the longitudinal axis of the vesicle.

\section{Belonechitina micracantha (Eisenack, 1931) group}

Description. The Belonechitina micracantha group shows a significant diversity in chamber shape as well as in ornamentation. Some specimens bear firm spines, fewer in number, others have numerous simple spines. The basal edge is rounded and the base is flattened to slightly swollen in some cases.

Stratigraphic range in the Dawangou section. NJ324-NJ374 (throughout the entire Saergan Formation and all of the described graptolite zones). 


\begin{tabular}{lcccccc}
\hline $\begin{array}{l}\text { Belonechitina } \\
\text { sp. 1 }\end{array}$ & $\begin{array}{c}\mathrm{L} \\
(\mu \mathrm{m})\end{array}$ & $\begin{array}{c}\mathrm{Dp} \\
(\mu \mathrm{m})\end{array}$ & $\begin{array}{c}\mathrm{Dc} \\
(\mu \mathrm{m})\end{array}$ & $\mathrm{Dp} / \mathrm{Dc}$ & $\mathrm{L} / \mathrm{Dp}$ & $\mathrm{L} / \mathrm{Dc}$ \\
\hline Average & 541.4 & 127.4 & 124.8 & 1.03 & 4.26 & 4.34 \\
Max & 660.0 & 140.0 & 140.0 & 1.38 & 5.18 & 5.18 \\
Min & 290.0 & 110.0 & 80.0 & 0.89 & 2.64 & 3.38 \\
\hline
\end{tabular}

Dimensions of 21 complete vesicles of Belonechitina sp. 1.

Table 5. Dimensions of Belonechitina sp. 1.

Remarks. In total, we classified 628 vesicles in this group. Some specimens are closely related to Belonechitina wesenbergensis, with long spines all over the vesicle walls, while others show the same kind of ornamentation as B. micracantha, but lacking the overall shape described by Eisenack (1965). Some specimens even show a tendency towards elongated spines, showing affinities with $B$. cf. henryi or - in extreme cases - even with the genus Hercochitina. But in these particular cases we were not able to distinguish the diagnostic characteristics from the affiliated species or genera.

\section{Belonechitina tuberculata (Eisenack, 1962) comb. nov.} (P1. 1, figs 1, 2)

Description. Chitinozoan vesicle with an inconspicuous flexure, a conical chamber and bearing spines evenly distributed all over the vesicle. The spines have a clear, round base but appear to end sharply. They are distributed densely near the base, and are less numerous on the upper part of the chamber. Following the suprageneric to generic classification scheme of Paris et al. (1999), we classify this species under the genus Belonechitina.

Stratigraphic range in the Dawangou section. NJ352 and NJ355 (Didymograptus murchisoni graptolite biozone).

Remarks. No complete vesicles were recovered, only fragments, but the presence of the rather distinctive spines allowed us to compare the vesicles to other specimens of Conochitina tuberculata described by Eisenack (1962) and with the detailed photographs of Nõlvak \& Bauert (2006) (pl. II, 8 and 8a). The descriptions given by both Eisenack (1962) and Nõlvak \& Bauert (2006) point towards a slender silhouette, while the specimens presented in the current paper suggest a stouter vesicle. But the solid basal parts of the spines are distinctive and present in both the Baltoscandian and Dawangou sections (Pl. 1, figs 1a, 2a). Because of the presence of spines it is more advisable to attribute this species to the genus Belonechitina.

\section{Belonechitina sp. 1 \\ (P1. 2, figs 1, 2)}

Description. Belonechitina sp. 1 has an inconspicuous flexure. The conical chamber - sometimes with straight flanks and hence rather cylindrical - is covered with spines. These simple spines are not elongated at the base, show no signs of bifurcations or any forms of crest-formation. The base is rounded to hemispherical. The specimens stand out within the genus because of their high vesicle length (Table 5).

Stratigraphic range in the Dawangou section. NJ328-NJ345 (Didymograptus murchisoni graptolite Subzone).
Belonechitina micracantha, B. sp. 1, B. sp.2

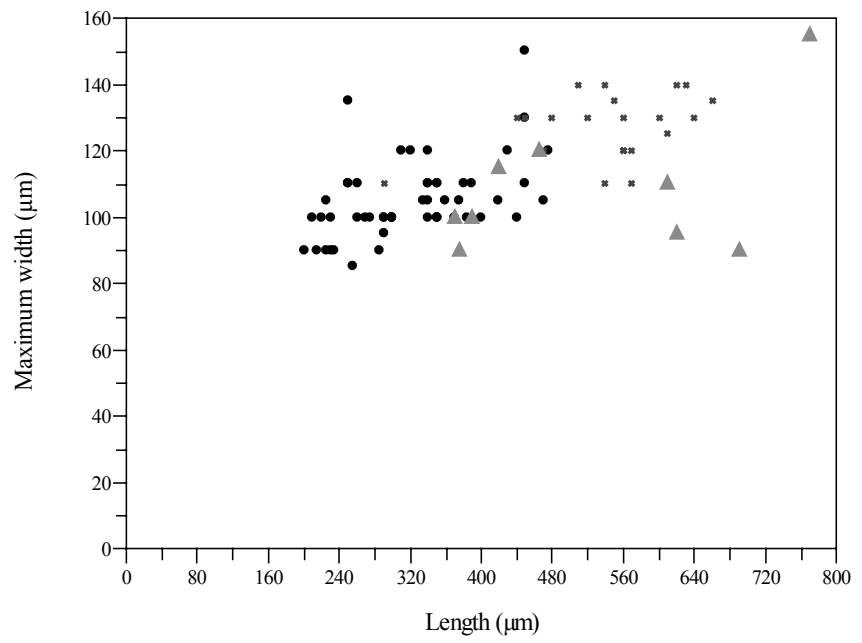

Fig. 4. Length-maximum width plot of Belonechitina sp. 2 (circles), Belonechitina micracantha (triangles) and Belonechitina sp. 1 (crosses).

Remarks. The overall appearance of the vesicle is similar to the genus Rhabdochitina, but this genus excludes species that bear spines, whereas the chamber of this species is covered with simple spines. The spines are similar to those of Belonechitina micracantha. Much like the latter species, B. sp. 1 has more and stouter spines showing at its aboral end, but, unlike B. micracantha, these are not more complex than the spines near the neck. Dimensions of the vesicles make it easy to distinguish both species. B. micracantha has a L/Dp ratio of $2.98, B$. sp. 1 has a $\mathrm{L} / \mathrm{Dp}$ ratio of 4.26. Belonechitina sp. 1 is clearly defined because of its length (average $541 \mu \mathrm{m}$ ) and its wide aperture (Table 5). The aboral end is not thickened, as in B. capitata. Because of the spiny, conical chamber, this species is included in the genus Belonechitina.

Belonechitina sp. 2

(P1. 2, figs 3, 4, 3a, 4a)

Description. Chitinozoan with a conical chamber, a very inconspicuous flexure and a test that clearly bears spines that are longer than $2 \mu \mathrm{m}$. The bases of these processes are elongated in some cases. The bottom is hemispherical and often a mucron is present (Pl. 2, figs 3, 3a). Spines completely cover the test, from the mucron to the aperture.

Stratigraphic range in the Dawangou section. NJ349-NJ373 (Didymograptus murchisoni graptolite zone and Nemagraptus gracilis graptolite Biozone).

Remarks. B. sp. 2 can be separated from $B$. sp. 1 based on its dimensions. The width of the neck of $B . \mathrm{sp} .2(\mathrm{~L} / \mathrm{Dc}=6.40)$ is a lot smaller compared to its total length than in the case of $B$. sp. 1 (L/Dc = 4.34). Consequently, a length-width scatter plot (Fig. 4; Table 6) can be used to separate both of the abovementioned species. This also accentuates the more conical shape of B. sp. 2. The ornamentation is somewhat similar to that of Hercochitina cf. spinetum, but the latter does not appear to have borne a mucron of any kind. The base of the latter species appears to be flat. 


\begin{tabular}{lcrrrrr}
\hline $\begin{array}{l}\text { Belonechitina } \\
\text { sp. 2 }\end{array}$ & $\begin{array}{c}\mathrm{L} \\
(\mu \mathrm{m})\end{array}$ & $\begin{array}{c}\mathrm{Dp} \\
(\mu \mathrm{m})\end{array}$ & $\begin{array}{c}\text { Dc } \\
(\mu \mathrm{m})\end{array}$ & Dp/Dc & L/Dp & L/Dc \\
\hline Average & 501.6 & 106.5 & 78.8 & 1.36 & 4.78 & 6.40 \\
Max & 790.0 & 155.0 & 100.0 & 1.93 & 7.90 & 10.53 \\
Min & 340.0 & 80.0 & 60.0 & 1.18 & 3.04 & 4.59 \\
\hline
\end{tabular}

Measurements on 14 complete vesicles of Belonechitina sp. 2.

Table 6. Dimensions of Belonechitina sp. 2.

\begin{tabular}{lcrcccc}
\hline $\begin{array}{l}\text { Belonechitina } \\
\text { sp. 3 }\end{array}$ & $\begin{array}{c}\mathrm{L} \\
(\mu \mathrm{m})\end{array}$ & $\begin{array}{c}\mathrm{Dp} \\
(\mu \mathrm{m})\end{array}$ & $\begin{array}{c}\mathrm{Dc} \\
(\mu \mathrm{m})\end{array}$ & Dp/Dc & $\mathrm{L} / \mathrm{Dp}$ & $\mathrm{L} / \mathrm{Dc}$ \\
\hline Average & 186.0 & 94.1 & 55.7 & 1.69 & 1.99 & 3.35 \\
Max & 250.0 & 110.0 & 60.0 & 2.00 & 2.78 & 4.17 \\
Min & 150.0 & 70.0 & 50.0 & 1.40 & 1.50 & 2.50 \\
\hline
\end{tabular}

Dimensions based on 21 vesicles of Belonechitina sp. 3 .

Table 7. Dimensions of Belonechitina sp. 3.

Belonechitina sp. 3

(P1. 2, figs 5, 6, 6a)

Description. Small conical vesicle with a conspicuous flexure and a spiny test. These spines are relatively long (>2 $\mu \mathrm{m})$ (Pl. 2, fig. 6a). The aperture is relatively wide and lacks a collarette. The base is relatively flat, the basal edges rounded. The maximum width of the chamber is half the total length $(\mathrm{L} / \mathrm{Dp}=1.99$, Table 7). The chamber forms about two-thirds of the total length.

Stratigraphic range in the Dawangou section. NJ363-NJ371 (Dicellograptus vagus and Nemagraptus gracilis graptolite Biozones).

Remarks. The ornamentation is comparable to that of B. hirsuta but not as densely implanted as the spines of the latter species. The overall shape is similar to that of Angochitina capillata, apart from the bottom which is flatter in the case of $B$. sp. 3. The rounded margins are reminiscent of Conochitina lepida, but this species has a smooth vesicle wall, and a stouter outline. This is reflected in the $\mathrm{L} / \mathrm{Dp}$ ratio, which is lower than the $\mathrm{L} / \mathrm{Dp}$ ratio of B. sp. 3 (1.55 for the holotype of C. lepida in Jenkins (1967) compared to 1.99 , Table 7 ).

\section{Genus Hercochitina Jansonius, 1964}

Hercochitina seriespinosa (Jenkins, 1969) comb. nov. (P1. 2, figs 7, 8, 7a)

Description. Hercochitina seriespinosa has a conical vesicle with rounded edges and a flat base. The maximum diameter lies at the base or, in some cases, midway along the chamber and is between one-third and half of the total length $(\mathrm{L} / \mathrm{Dp}=2.14$, Table 8). The ornamentation largely consists of simple straight or curving spines with pointed tips. Towards the base, the spines fuse and form clear ridges. This is certainly the case for the bottom half of the chamber. Towards the neck and on the neck itself simple spines can be found, shorter than those on the

\begin{tabular}{lccrccc}
\hline $\begin{array}{l}\text { Hercochitina } \\
\text { seriespinosa }\end{array}$ & $\begin{array}{c}\mathrm{L} \\
(\mu \mathrm{m})\end{array}$ & $\begin{array}{c}\mathrm{Dp} \\
(\mu \mathrm{m})\end{array}$ & $\begin{array}{c}\mathrm{Dc} \\
(\mu \mathrm{m})\end{array}$ & $\mathrm{Dp} / \mathrm{Dc}$ & $\mathrm{L} / \mathrm{Dp}$ & $\mathrm{L} / \mathrm{Dc}$ \\
\hline Average & 249.2 & 117.5 & 81.7 & 1.44 & 2.14 & 3.08 \\
Max & 280.0 & 140.0 & 100.0 & 1.63 & 2.60 & 3.71 \\
Min & 210.0 & 100.0 & 70.0 & 1.38 & 1.69 & 2.63 \\
\hline
\end{tabular}

Measurements on 6 complete vesicles of Hercochitina seriespinosa.

Table 8. Dimensions of Hercochitina seriespinosa.

chamber wall, which are clearly separated from each other. Sometimes the ridges show openings near their bases. This gives the impression of proximally furcated, $\lambda$-spines covering the test.

Stratigraphic range in the Dawangou section. NJ331 (Didymograptus murchisoni graptolite Biozone).

Remarks. Jenkins (1969) placed the species in the genus Conochitina because the tips are not connected by means of longitudinal bars (e.g. Hercochitina spinetum). But, given that the conical vesicle is covered with crests (web-like to continuous membranes, diagnostic characteristic of the genus Hercochitina, as shown by Paris et al. (1999, fig. 2.11)), we assign this species to the genus Hercochitina, following the classification schemes of Jansonius (1964) and Paris et al. (1999). The specimens described by Jenkins (1969) are smaller (with an average total length of $163 \mu \mathrm{m})$ compared to our specimens' total average length of $243 \mu \mathrm{m}$ (Table 8 ). The ornamentation, however, is the distinctive feature of this species and the processes of the Dawangou specimens match the holotype description given by Jenkins (1969) - not connected at the top but forming continuous membranes.

\section{Hercochitina sp. 1}

(Pl. 2, figs 9, 10, 9a)

Description. Hercochitina sp. 1 has a nearly cylindrical neck and inconspicuous flexure connecting the neck with the conical chamber. The vesicle bears fine slender spines with clearly elongated bases. Because the crests are very subtle, the vesicle appears to be striated. At higher magnification (Pl. 2, fig. 9a), however, we can see clearly that these striations really are spiny structures. Just above the base of the vesicle, the spines are better developed with elongated, crest-like bases.

Stratigraphic range in the Dawangou section. NJ324 (Pterograptus elegans graptolite Biozone)-NJ331 and NJ336 Didymograptus murchisoni graptolite Subzone).

Remarks. The crests of $H$. sp. 1 are longer than those found on Hercochitina seriespinosa, in some cases measuring up to onethird of the total length of the vesicle (Table 9). Some spines near the oral pole look like the spines with elongated bases from Belonechitina cf. henryi. The chamber shape of the latter differs clearly from $H$. sp. 1 ; it is much wider, making it easy to distinguish the two. The chamber of $H$. sp. 1 is strictly conical with a slightly flattened base. This chamber shape is comparable to that of $H$. seriespinosa, but the latter is much smaller and bears well-developed spines. 


\begin{tabular}{lccrccc}
\hline $\begin{array}{l}\text { Hercochitina } \\
\text { sp. 1 }\end{array}$ & $\begin{array}{c}\mathrm{L} \\
(\mu \mathrm{m})\end{array}$ & $\begin{array}{c}\mathrm{Dp} \\
(\mu \mathrm{m})\end{array}$ & $\begin{array}{c}\mathrm{Dc} \\
(\mu \mathrm{m})\end{array}$ & $\mathrm{Dp} / \mathrm{Dc}$ & $\mathrm{L} / \mathrm{Dp}$ & $\mathrm{L} / \mathrm{Dc}$ \\
\hline Average & 307.2 & 106.8 & 82.0 & 1.30 & 2.96 & 3.80 \\
Max & 480.0 & 180.0 & 110.0 & 1.64 & 4.80 & 5.83 \\
Min & 210.0 & 80.0 & 60.0 & 1.00 & 1.17 & 1.91 \\
\hline
\end{tabular}

Measurements on 25 complete vesicles of Hercochitina sp. 1.

Table 9. Dimensions of Hercochitina sp. 1.

\begin{tabular}{lccrrrr}
\hline $\begin{array}{l}\text { Lagenochitina } \\
\text { pirum }\end{array}$ & $\begin{array}{c}\mathrm{L} \\
(\mu \mathrm{m})\end{array}$ & $\begin{array}{c}\mathrm{Dp} \\
(\mu \mathrm{m})\end{array}$ & $\begin{array}{c}\mathrm{Dc} \\
(\mu \mathrm{m})\end{array}$ & $\mathrm{Dp} / \mathrm{Dc}$ & $\mathrm{L} / \mathrm{Dp}$ & $\mathrm{L} / \mathrm{Dc}$ \\
\hline Average & 406.9 & 191.7 & 92.6 & 2.10 & 2.15 & 4.46 \\
Max & 620.0 & 265.0 & 240.0 & 3.25 & 4.62 & 6.89 \\
Min & 240.0 & 100.0 & 55.0 & 1.08 & 1.30 & 2.52 \\
\hline
\end{tabular}

Dimensions based on 159 complete specimens of Lagenochitina pirum.

Table 10. Dimensions of Lagenochitina pirum.

Family Lagenochitinidae Eisenack, 1931

Sub-family Lagenochitininae Paris, 1981

Genus Lagenochitina Eisenack, 1931

Lagenochitina pirum (Achab, 1982)

(P1. 3, figs 1-3, 3a, 3b)

Description. The chamber and neck are well differentiated. The neck is cylindrical and, in general, shorter than the chamber. This chamber is about twice as wide as the neck $(\mathrm{Dp} / \mathrm{Dc}=2.08$, Table 10). The maximum width, about half the total length $(\mathrm{L} / \mathrm{Dp}=2.15$, Table 10) can be found in the bottom half of the chamber. On the whole, the overall shape is best described as pear-shaped (Achab, 1982). Lagenochitina pirum has rounded basal edges and a flattened base. The test is covered with granules. These can be large and densely implanted (Pl. 3, fig. 3a).

Stratigraphic range in the Dawangou section. NJ328, NJ338NJ349, NJ352, NJ355-NJ358, NJ361-NJ369 and NJ371-NJ373 (throughout the Saergan Formation and the following grapolite biozones: the Pterograptus elegans Biozone, the Didymograptus murchisoni Biozone, the Dicellograptus vagus Biozone and the Nemagraptus gracilis Biozone).

Remarks. Lagenochitina pirum can be differentiated from Fustichitina langei by its wider chamber. A few specimens are virtually bottle shaped, leaning towards Lagenochitina baltica, but $L$. pirum is notably bigger (Fig. 5) and, averaged over the whole assemblage, the pear-shape typical form of $L$. pirum clearly dominates. The maximum dimensions of $L$. baltica, described by Grahn (1982) are about the same as those of smaller specimens of $L$. pirum from this study, while the average size of L. pirum from the Dawangou section is larger than that $\left(D p_{\text {average }}=191 \mu \mathrm{m}\right)$. The specimens described in Achab (1983) have a very short neck, while the specimens found in the Saergan Formation have a more obvious flexure and a longer neck. Achab (1982) states that with the optical microscope the vesicles appear to bear ornamentation of some kind, but that scanning

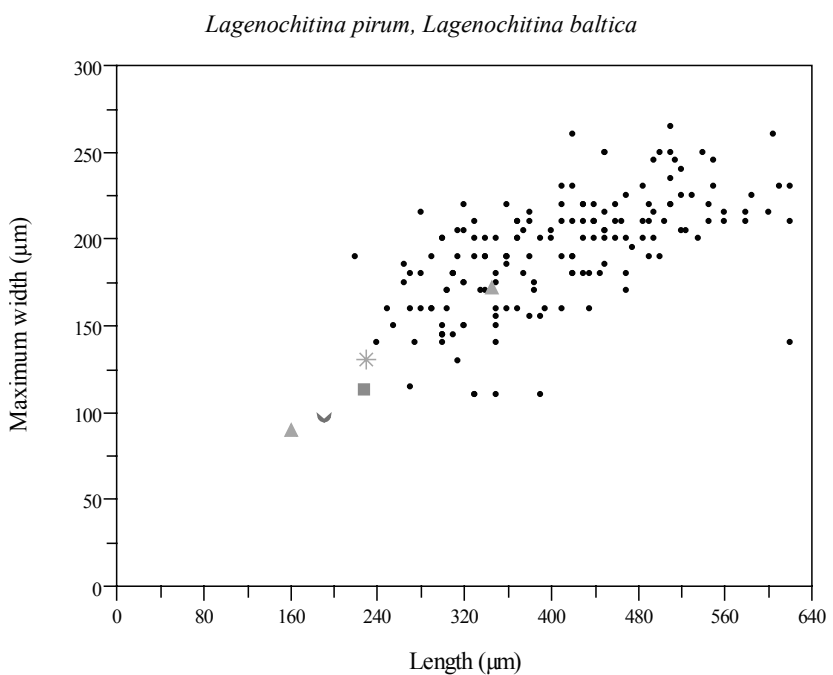

Fig. 5. Length-maximum width plot of Lagenochitina pirum from this study (black circles), the minimum and maximum dimensions of Lagenochitina baltica from Grahn (1982) (grey triangles) and the mean value of Lagenochitina baltica from Vandenbroucke (2008a) (Whitland section, grey square; Cautley District, grey star; Pus Gill section, grey half circle).

electron microscopy reveals that they are, in fact, smooth, while our specimens clearly bear granules (Pl. 3, fig 3a). However, Achab (1983) mentions that the granules, if present, corrode easily. Achab $(1982,1983)$ placed this species within the genus Conochitina. Achab (1983) mentioned that because of the clear flexure and because of its general silhouette, it is possible that the Canadian Conochitina pirum could be included in the genera Lagenochitina or Fustichitina. Following Albani et al. (2001), we include this species in the genus Lagenochitina, because of the clear flexure and also the test covered with small granules, common within the genus Lagenochitina.

\section{Lagenochitina sp. 1}

(Pl. 3, figs 4, 5)

Description. The flanks of Lagenochitina sp. 1 are swollen, which gives the chamber a spherical shape. The vesicle wall appears to bear minute granules in some cases, while others show no signs of ornamentation whatsoever. The neck of Lagenochitina sp. 1 is relatively wide, about half the width of the swollen chamber. The base is flat, in many cases, but clearly rounded in some others. The maximum width is located halfway along the vesicle chamber.

Stratigraphic range in the Dawangou section. NJ343-NJ349 (Didymograptus murchisoni graptolite subzone).

Remarks. The overall shape of $L$. sp. 1 is comparable to the silhouette of Lagenochitina deunffi. The latter, however, has a very narrow, small neck while the neck of $L$. sp. 1 is rather wide, about half the maximum width $(\mathrm{Dp} / \mathrm{Dc}=1.99$, Table 11$)$. Some specimens resemble Lagenochitina brevicollis, but the characteristic colarette is absent in the Dawangou specimens. Other specimens could be compared to Lagenochitina obeligis described by Paris (1981), but the maximum width of this species 


\begin{tabular}{lccrccc}
\hline $\begin{array}{l}\text { Lagenochitina } \\
\text { sp. 1 }\end{array}$ & $\begin{array}{c}\mathrm{L} \\
(\mu \mathrm{m})\end{array}$ & $\begin{array}{c}\mathrm{Dp} \\
(\mu \mathrm{m})\end{array}$ & $\begin{array}{c}\mathrm{Dc} \\
(\mu \mathrm{m})\end{array}$ & $\mathrm{Dp} / \mathrm{Dc}$ & $\mathrm{L} / \mathrm{Dp}$ & $\mathrm{L} / \mathrm{Dc}$ \\
\hline Average & 323.3 & 187.5 & 94.6 & 1.99 & 1.72 & 3.40 \\
Max & 470.0 & 250.0 & 125.0 & 2.39 & 2.47 & 4.20 \\
Min & 210.0 & 140.0 & 70.0 & 1.68 & 1.16 & 2.63 \\
\hline
\end{tabular}

Measurements on 26 complete vesicles of Lagenochitina sp. 1.

Table 11. Dimensions of Lagenochitina sp. 1.

\begin{tabular}{lccrrrr}
\hline $\begin{array}{l}\text { Lagenochitina } \\
\text { sp. } 2\end{array}$ & $\begin{array}{c}\mathrm{L} \\
(\mu \mathrm{m})\end{array}$ & $\begin{array}{c}\mathrm{Dp} \\
(\mu \mathrm{m})\end{array}$ & $\begin{array}{c}\mathrm{Dc} \\
(\mu \mathrm{m})\end{array}$ & $\mathrm{Dp} / \mathrm{Dc}$ & $\mathrm{L} / \mathrm{Dp}$ & $\mathrm{L} / \mathrm{Dc}$ \\
\hline Average & 340.0 & 193.3 & 85.0 & 2.26 & 1.76 & 3.96 \\
Max & 440.0 & 250.0 & 100.0 & 2.50 & 2.00 & 4.40 \\
Min & 260.0 & 160.0 & 75.0 & 2.00 & 1.53 & 3.47 \\
\hline
\end{tabular}

Measurements on 3 complete vesicles of Lagenochitina sp. 2.

Table 12. Dimensions of Lagenochitina sp. 2.

is located more towards the base than is the case for $L$. sp. 1 . Lagenochitina capax is comparable in shape but bears clear ornamentation and is about one-third the size of Lagenochitina sp. 1.

\section{Lagenochitina sp. 2}

(P1. 3, fig. 6)

Description. Lagenochitina sp. 2 has an ovoid chamber; some specimens have a more flask-shaped chamber covered with granules smaller than $2 \mu \mathrm{m}$. These granules are more developed near the aboral pole. This species has a wide collarette and an inconspicuous flexure.

Stratigraphic range in the Dawangou section. NJ365, NJ369, NJ371 (Nemagraptus gracilis graptolite Biozone).

Remarks. Typical for this species is the presence of a collarette somewhat comparable to those found on Lagenochitina esthonica, but a bit smaller in the present case. The latter, however, has a narrower neck and a clearer flexure. The chamber of $L$. sp. 2 is also wider and longer (Table 12). The collarette and the coarse granules are the distinctive features for separating this species from other species within the genus Lagenochitina described at the Dawangou section.

Lagenochitina sp. 3

(Pl. 3, figs 9-11, 10a, 11a)

Description. Clear flexure, well-developed granules, ovoid chamber. The neck is a very distinctive element for this species. It is cylindrical, straight, narrow and very long (up to half the total length). The maximum width is situated about halfway along the vesicle chamber. The maximum length measured here is $650 \mu \mathrm{m}$. With an average length of $528 \mu \mathrm{m}$ (Table 13), this is an exceptionally long species in the genus Lagenochitina.

Stratigraphic range in the Dawangou section. NJ347, NJ355 (Didymograptus murchisoni graptolite subzone) and NJ361-

\begin{tabular}{lccrccc}
\hline $\begin{array}{l}\text { Lagenochitina } \\
\text { sp. 3 }\end{array}$ & $\begin{array}{c}\mathrm{L} \\
(\mu \mathrm{m})\end{array}$ & $\begin{array}{c}\mathrm{Dp} \\
(\mu \mathrm{m})\end{array}$ & $\begin{array}{c}\mathrm{Dc} \\
(\mu \mathrm{m})\end{array}$ & $\mathrm{Dp} / \mathrm{Dc}$ & $\mathrm{L} / \mathrm{Dp}$ & $\mathrm{L} / \mathrm{Dc}$ \\
\hline Average & 528.3 & 209.1 & 94.7 & 2.24 & 2.53 & 5.70 \\
Max & 650.0 & 230.0 & 130.0 & 2.81 & 3.10 & 7.75 \\
Min & 370.0 & 190.0 & 80.0 & 1.62 & 1.95 & 3.62 \\
\hline
\end{tabular}

Measurements on 18 complete vesicles of Lagenochitina sp. 3.

Table 13. Dimensions of Lagenochitina sp. 3.

NJ369 (Didymograptus murchisoni, Dicellograptus vagus and Nemagraptus gracilis graptolite Biozones).

Remarks. The base is somewhat flat, which separates them from Lagenochitina aff. inflata. The chamber of L. sp. 3 is comparable to that of $L$. pirum, except that the ornamentation is more developed.

Lagenochitina sp. 4

(Pl. 3, fig. 8)

Description. The chamber of this species bears granules, and is straight to slightly ovoid and the flexure is inconspicuous. The base is convex. The neck is wide (almost half the maximum length, $\mathrm{Dp} / \mathrm{Dc}=1.89$, Table 14).

Stratigraphic range in the Dawangou section. NJ347, NJ349 (Didymograptus murchisoni graptolite subzone), NJ363 (Dicellograptus vagus graptolite Subzone) and NJ369 (Nemagraptus gracilis graptolite Biozone).

Remarks. The chamber reveals a granulate ornamentation comparable to the other species described within this genus. The difference with the other species is the absence of a clear flexure. On average, Lagenochitina sp. 4 is smaller than Lagenochitina pirum. Maybe this species might be better assigned to the genus Conochitina because of the absence of clearly distinguishable shoulders, but, because of its granulate nature, it is most comparable to the other Lagenochitina recognized in the Dawangou section.

\section{Lagenochitina sp. A sensu Achab, 1984}

(Pl. 4, figs 1-4, 3a, 4a)

Description. Chitinozoan with a granulate test, convex flanks, relatively flat base and cylindrical neck. The granules are a distinctive element for this species. The granules are connected to form scale-like structures (Pl. 4, fig. 4a). When the specimens are poorly preserved and the scale-like ornamentation is broken and flattened, they form very typical wrinkles (P1. 4, fig. 3a).

Stratigraphic range in the Dawangou section. NJ371-NJ374 (Nemagraptus gracilis graptolite biozone).

Remarks. The specimens from the Saergan Formation closely match the description given by Achab (1984). Because of the flat base and the distinct shoulders, some specimens tend to display the flask shape typical of Lagenochitina baltica. But L. sp. A is notably more elongate (Table 15). The specimens with a more 


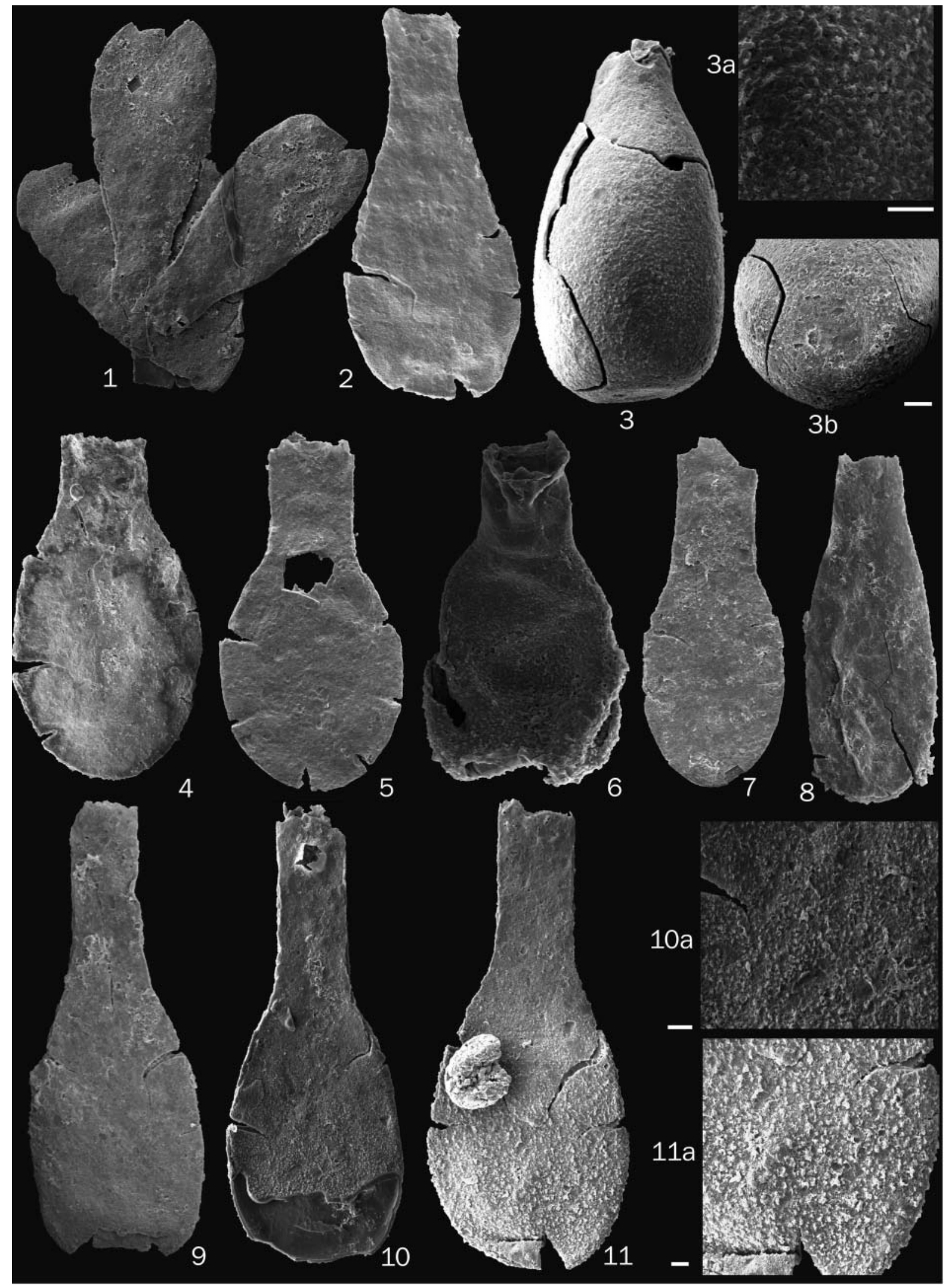




\begin{tabular}{lccrccc}
\hline $\begin{array}{l}\text { Lagenochitina } \\
\text { sp. } 4\end{array}$ & $\begin{array}{c}\mathrm{L} \\
(\mu \mathrm{m})\end{array}$ & $\begin{array}{c}\mathrm{Dp} \\
(\mu \mathrm{m})\end{array}$ & $\begin{array}{c}\mathrm{Dc} \\
(\mu \mathrm{m})\end{array}$ & $\mathrm{Dp} / \mathrm{Dc}$ & $\mathrm{L} / \mathrm{Dp}$ & $\mathrm{L} / \mathrm{Dc}$ \\
\hline Average & 366.1 & 156.2 & 83.2 & 1.89 & 2.36 & 4.42 \\
Max & 480.0 & 210.0 & 105.0 & 2.71 & 2.94 & 6.27 \\
Min & 205.0 & 105.0 & 60.0 & 1.40 & 1.79 & 2.73 \\
\hline
\end{tabular}

Measurements on 17 complete vesicles of Lagenochitina sp. 4.

Table 14. Dimensions of Lagenochitina sp. 4.

convex base have a silhouette similar to that of Fustichitina langei, described by Achab (1980), but the scale-like ornamentation of $L$. sp. A sensu Achab, 1980 is very distinctive (P1. 4, figs 3a, 4a). This is also the key characteristic to distinguish L. pirum from L. sp. A sensu Achab, 1980. Furthermore, Lagenochitina sp. A can be separated from Lagenochitina aff. ponceti sensu Vandenbroucke, 2004 by its ornamentation, largely absent in the latter, and its flatter base, rounder in the case of $L$. aff. poncet $i$ sensu Vandenbroucke, 2004.

Subfamily Cyathochitininae Paris, 1981

Genus Cyathochitina Eisenack, 1955 emend. Paris et al., 1999

Cyathochitina campanulaeformis (Eisenack, 1931)

(P1. 4, figs 5-7, 6a, 7a)

Description. Chitinozoan species with a conspicuous flexure and glabrous vesicle wall and with an obvious carina on the basal margin. The chamber shape is best described as conical, although there is a lot of variation in chamber shape ranging from a near perfect conical shape (Pl. 4, fig. 5) to slightly bulbous shoulders and chamber (Pl. 4, fig. 7).

Stratigraphic range in the Dawangou section. NJ328-NJ353, NJ356-NJ365 and NJ371 (throughout the entire Saergan Formation and the graptolite biozones described herein).

Remarks. The overall shape of Cyathochitina campanulaeformis shows an important polymorphism. Some forms show a close relation with $C$. calix, with a clearly differentiated neck and a slender chamber, while others show affinities with C. kuckersiana, with a shorter neck, a stout, wide chamber and a wide carina. The measurements in Table 16 and the length-width plot of Figure 6 show this variation. As we cannot distinguish different assemblages in the length-width scatter plots, all these specimens were assigned to the same species. Some individuals have a constriction just above the carina. Other individuals bear transversal crests around the chamber (Pl. 4, figs 6a, 7a), which are not mere ornamentations, in which only the outer wall is involved, but they are much thicker, also the inner wall is involved. Neville (1974) shows pictures of $C$. jenkinsi with the

\begin{tabular}{lcccccc}
\hline $\begin{array}{l}\text { Lagenochitina } \\
\text { sp. A }\end{array}$ & $\begin{array}{c}\mathrm{L} \\
(\mu \mathrm{m})\end{array}$ & $\begin{array}{c}\mathrm{Dp} \\
(\mu \mathrm{m})\end{array}$ & $\begin{array}{c}\text { Dc } \\
(\mu \mathrm{m})\end{array}$ & Dp/Dc & L/Dp & L/Dc \\
\hline Average & 376.6 & 133.0 & 78.0 & 1.72 & 2.85 & 4.83 \\
Max & 530.0 & 160.0 & 90.0 & 2.07 & 4.42 & 6.07 \\
Min & 185.0 & 100.0 & 60.0 & 1.33 & 1.61 & 3.08 \\
\hline
\end{tabular}

Measurements on 22 complete vesicles of Lagenochitina sp. A sensu Achab, 1984.

Table 15. Dimensions of Lagenochitina sp. A sensu Achab, 1984.

same kind of horizontal bands. The distinction between the different species of the genus Cyathochitina remains very difficult. Paris (1981) states that the carina of C. kuckersiana is wider than $25 \mu \mathrm{m}$, while it is shorter in the case of $C$. calix and $C$. campanulaeformis. Although the specimens appear to be more elongate in the Dawangou section ( $\mathrm{L} / \mathrm{Dp}=2.21$, Table 16$)$ in comparison with $C$. campanulaeformis specimens from Paris (1981: $\mathrm{L} / \mathrm{Dp}=1.6$ ) and Jenkins (1967: L/Dp $=1.6$ ), the specimens retrieved in the present study show no other affinities with C. calix, C. kuckersiana or C. jenkinsi. Taking into account the characteristic carina length proposed by Paris (1981), our specimens are assigned to C. campanulaeformis.

\section{Cyathochitina giraffa sp. nov.}

(P1. 4, figs 8-11, 11a)

2007 Cyathochitina sp. A Tang et al.: 482, fig. 19.

2001 Cyathochitina sp. cf. C. jenkinsi Ottone et al.: 109, pl. 3, figs $6,8,9$.

2000 Cyathochitina jenkinsi Geng et al.: pl. 4, fig. 8.

1984 Cyathochitina sp. cf. C. jenkinsi Achab: 135, pl. V, figs 1-9.

Derivation. The long neck of this Cyathochitina species resembles the neck of a giraffe.

Holotype. L: $395 \mu \mathrm{m}$; Dp: $140 \mu \mathrm{m}$; Dc: $70 \mu \mathrm{m}$.

RBINS collection number. IRSNB b 5100, IRSNB b 5101, IRSNB b 5102 and IRSNB b 5103 (holotype).

Discussion. The vesicle typically has a long (neck length/total length is at least 0.4 and often higher than 0.5 ), cylindrical and straight neck. It is half as wide as the maximum width $(\mathrm{Dp} / \mathrm{Dc}=$ 2.01, Table 17). In most of the specimens this maximum width is located at a distance of one-fifth of the total chamber length above the vesicle base. The chamber is triangular shaped until it reaches its maximum diameter. Aborally from this point, the flanks bend back towards the central axis of the vesicle, expressing a clear constriction above the base of the chamber. A carina, typical for a Cyathochitina, is present on the basal margin.

Explanation of Plate 3.

fig. 1. Lagenochitina pirum cluster (sample NJ355). figs 2, 3. Lagenochitina pirum: 2, $420 \times 190 \times 75$ (sample NJ349); 3, $275 \times 140 \times 60$ (sample NJ369) - 3a, detail of 3, 3b, bottom of 3 with basal scar (scale bars $10 \mu \mathrm{m}$ ). figs 4, 5. Lagenochitina sp. 1: 4, $350 \times 200 \times 90$ (sample NJ347); $\mathbf{5}$, $470 \times 250 \times 125$ (sample NJ349) - 5a, detail of 5 (scale bar $10 \mu \mathrm{m})$. fig. 6. Lagenochitina sp. $2(260 \times 170 \times 75$ (sample NJ369). fig. 7 . Lagenochitina aff. ponceti sensu Vandenbroucke, $2004(450 \times 190 \times 125$ (sample NJ349). fig. 8. Lagenochitina sp. $4(320 \times 120 \times 60($ sample NJ369). figs 9-11. Lagenochitina sp. 3: 9, $560 \times 220 \times 90$ (sample NJ355); 10, $555 \times 195 \times 85$ (sample NJ363) - 10a, detail of 10 (scale bar $10 \mu$ m); 11, $480 \times 215 \times 90($ sample NJ365) - 11a, detail of 11 (scale bar $10 \mu \mathrm{m})$. 


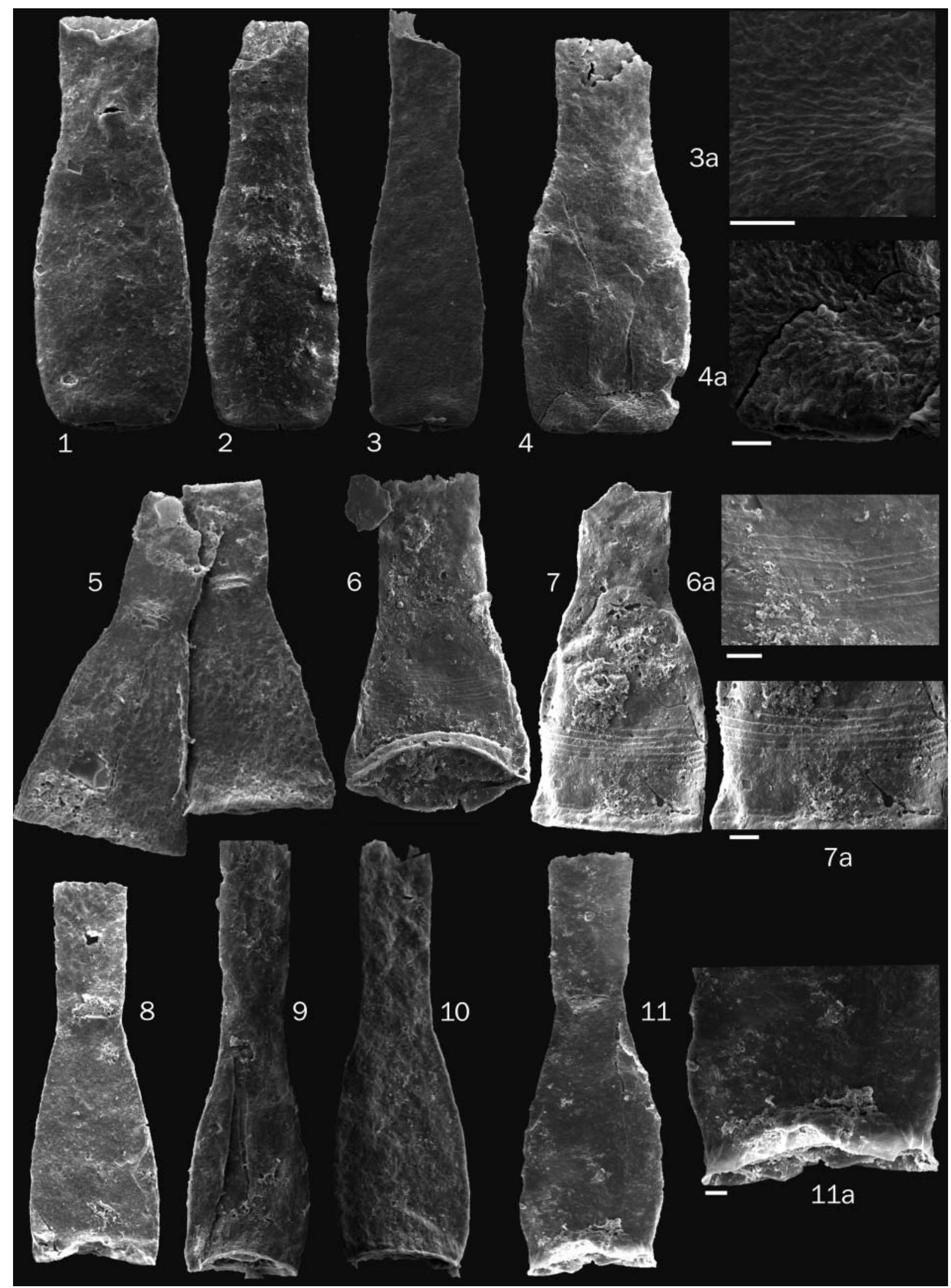




\begin{tabular}{lcrrrrr}
\hline $\begin{array}{l}\text { Cyathochitina } \\
\text { campanulaeformis }\end{array}$ & $\begin{array}{c}\mathrm{L} \\
(\mu \mathrm{m})\end{array}$ & $\begin{array}{c}\mathrm{Dp} \\
(\mu \mathrm{m})\end{array}$ & $\begin{array}{c}\mathrm{Dc} \\
(\mu \mathrm{m})\end{array}$ & $\mathrm{Dp} / \mathrm{Dc}$ & $\mathrm{L} / \mathrm{Dp}$ & $\mathrm{L} / \mathrm{Dc}$ \\
\hline Average & 285.1 & 163.3 & 74.1 & 2.21 & 1.78 & 3.88 \\
Max & 490.0 & 290.0 & 105.0 & 4.14 & 5.00 & 6.40 \\
Min & 130.0 & 75.0 & 40.0 & 1.14 & 1.07 & 2.35 \\
\hline
\end{tabular}

Measurements on 1256 complete vesicles of Cyathochitina campanulaeformis.

Table 16. Dimensions of Cyathochitina campanulaeformis.

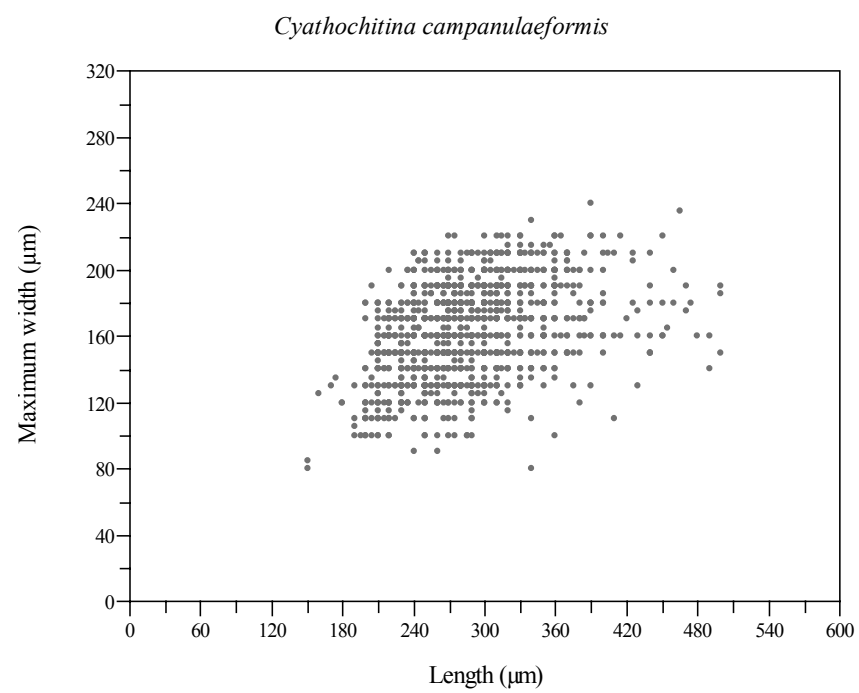

Fig. 6. Length-maximum width plot of Cyathochitina campanulaeformis.

Stratigraphic range in the Dawangou section. NJ331, NJ335, NJ340, NJ344, NJ349-NJ352, NJ370-NJ372 (in the Didymograptus murchisoni Biozone, Dicellograptus vagus Subzone and Nemagraptus gracilis Biozone).

Remarks. The carina of $C$. giraffa sp. nov. has a length intermediate between the length of the carina of $C$. calix and $C$. campanulaeformis. The most important difference with $C$. campanulaeformis is the position of the maximum width and the long neck. On average, C. campanulaeformis has a conical chamber with the maximum width appearing at or very close to the basal edges. The most important difference with $C$. jenkinsi in Neville (1974) is the chamber test. Neville (1974) describes longitudinal ridges, clearly visible near the aboral pole of the vesicle. These ridges are not present in any of the specimens recovered from the Dawangou section. Some specimens of $C$. giraffa sp. nov. show affinities with $C$. calix described by Grahn (1981b), but the neck of the former is typically longer (more than half of the total length) and more slender. Achab (1984: 135, pl. 5, fig. 9), however, shows a specimen of Cyathochitina $\mathrm{cf}$.

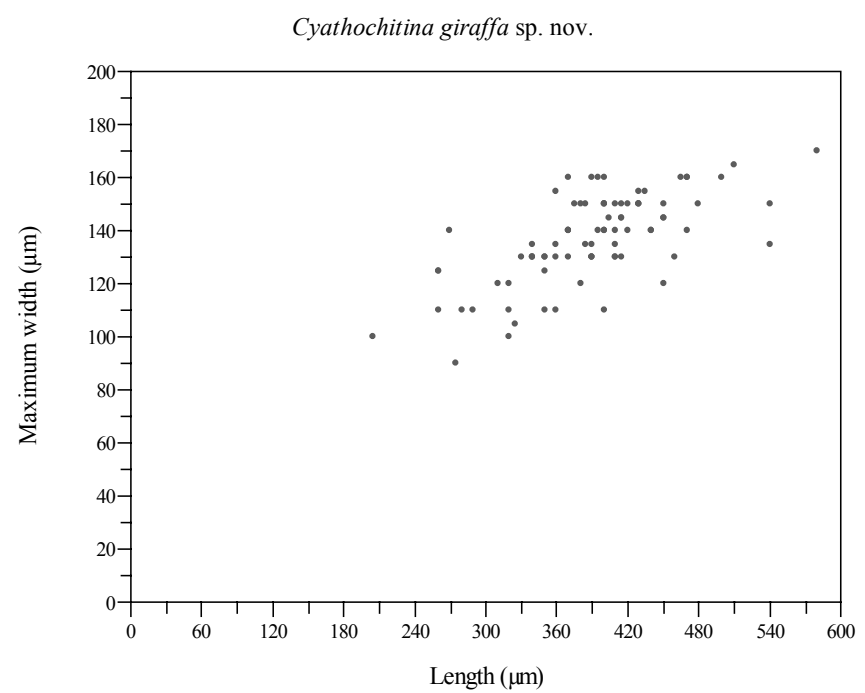

Fig. 7. Length-maximum width plot of Cyathochitina giraffa sp. nov.

\begin{tabular}{lcccccc}
\hline $\begin{array}{l}\text { Cyathochitina } \\
\text { giraffa }\end{array}$ & $\begin{array}{c}\mathrm{L} \\
(\mu \mathrm{m})\end{array}$ & $\begin{array}{c}\mathrm{Dp} \\
(\mu \mathrm{m})\end{array}$ & $\begin{array}{c}\mathrm{Dc} \\
(\mu \mathrm{m})\end{array}$ & $\mathrm{Dp} / \mathrm{Dc}$ & $\mathrm{L} / \mathrm{Dp}$ & $\mathrm{L} / \mathrm{Dc}$ \\
\hline Average & 399.3 & 140.0 & 69.8 & 2.01 & 2.86 & 5.74 \\
Max & 580.0 & 190.0 & 90.0 & 2.50 & 4.00 & 9.00 \\
Min & 260.0 & 100.0 & 50.0 & 1.33 & 1.93 & 3.60 \\
\hline
\end{tabular}

Measurements on 89 complete cysts of Cyathochitina giraffa sp. nov.

Table 17. Dimensions of Cyathochitina giraffa sp. nov.

C. jenkinsi with a very short neck. The chamber shape of this latter specimen is completely according to the description given above; hence, it is placed in synonymy with the Dawangou specimens.

\section{CONCLUSIONS}

Thirty-two samples were analysed from the Dawangou section of China, covering four graptolite biozones. A total of 6536 chitinozoan vesicles were recovered and measured. Within this assemblage we were able to recognize three chitinozoan biozones, two of which were originally defined by Nõlvak \& Grahn (1993) in Baltoscandia - the Laufeldochitina striata Biozone and the Belonechitina tuberculata Subzone - and one defined by Achab (1989) in Laurentia - the Lagenochitina sp. A (Belonechitina hirsuta) Biozone. One Baltoscandian biozone was provisionally recognized: the Laufeldochitina stentor Biozone on the basis of the occurrence of Laufeldochitina sp. A aff. striata sensu Grahn et al., 1996. This biozonation enables us to correlate the Dawangou section with chitinozoans from other palaeocontinents (Fig. 3). Among the recovered chitinozoan vesicles we were unable to identify Eisenackitina rhenana, which is the index species for the subzone that comprises the base for the Upper

\section{Explanation of Plate 4.}

figs 1-4. Lagenochitina sp. A (Achab, 1984) (scale bars $10 \mu \mathrm{m}): \mathbf{1}, 345 \times 130 \times 85$ (sample NJ373); 2, $410 \times 135 \times 80$ (sample NJ373); 3, $460 \times 125 \times 80$ (sample NJ373) - 3a, detail of 3; 4, $350 \times 150 \times 80$ (sample NJ373) - 4a, detail of 4. figs 5-7. Cyathochitina campanulaeformis:

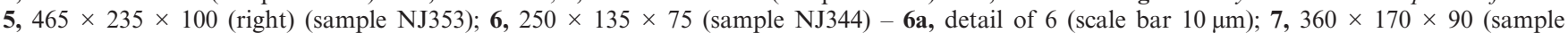
NJ331) - 7a, detail of 7 (scale bar $25 \mu \mathrm{m})$. figs 8-11. Cyathochitina giraffa sp. nov.: 8, $410 \times 140 \times 70($ sample NJ340); 9, $400 \times 110 \times 65($ sample NJ373); 10, $395 \times 140 \times 70$ (sample NJ352); 11, $350 \times 110 \times 65$ (sample NJ373) - 11a, detail of 11 (scale bar $10 \mu \mathrm{m})$. 
Ordovician Series at the GSSP locality in Fågelsång (Sweden). However, the Auxiliary Stratotype Section of Dawangou can be linked to the GSSP of Fågelsång by means of chitinozoans using the Laufeldochitina striata Biozone and the Belonechitina tuberculata Subzone (Fig. 3).

During this study we encountered a large endemic assemblage of specimens belonging to the genera Lagenochitina, Belonechitina and Cyathochitina. One new species was formally described: Cyathochitina giraffa sp. nov., while two species were assigned to a different genus: Belonechitina tuberculata comb. nov. and Hercochitina seriespinosa comb. nov.

\section{ACKNOWLEGEMENTS}

The authors wish to thank Gary Mullins, Nick Miles and the editor, F. John Gregory, for helpful and constructive suggestions during the review process. TVDB thanks the Research Foundation - Flanders (FWO Flanders) for post-doc funding; Ghent University (Belgium) was the host institution for TVDB and $\mathrm{JH}$.

\section{Manuscript received 9 February 2010 Manuscript accepted 10 July 2010}

Scientific editing by F. John Gregory

\section{REFERENCES}

Achab, A. 1980. Chitinozoaires de l'Arenig inférieur de la Formation de Lévis (Québec, Canada). Review of Palaeobotany and Palynology, 31: 219-239.

Achab, A. 1982. Chitinozoaires de l'Arenig supérieur (Zone D) de la Formation de Lévis, Québec, Canada. Canadian Journal of Earth Sciences, 19: 1295-1307.

Achab, A. 1983. Chitinozoaires du Llanvirn (formation de Table Head) de la partie occidentale de Terre-Neuve, Canada. Canadian Journal of Earth Sciences, 20: 918-931.

Achab, A. 1984. Chitinozoaires de l'Ordovicien moyen de subsurface de l'Ile Anticosti. Review of Palaeobotany and Palynology, 43: 123-143.

Achab, A. 1986. Succession des assemblages de chitinozoaires dans l'Ordovicien moyen du Québec et de l'est du Canada. Review of Palaeobotany and Palynology, 48: 269-294.

Achab, A. 1989. Ordovician chitinozoan zonation of Quebec and western Newfoundland. Journal of Paleontology, 63: 14-24.

Albani, R., Bagnoli, G., Maletz, J. \& Stouge, S. 2001. Integrated chitinozoan, conodont, and graptolite biostratigraphy from the upper part of the Cape Cormorant Formation (Middle Ordovician), western Newfoundland. Canadian Journal of Earth Sciences, 38: 387-409.

Bengtson, P. 1988. Open nomenclature. Palaeontology, 32(1): 223-227.

Bergström, S.M., Finney, S.C., Chen, X. \& Wang, Z. 1998. The base of the Nemagraptus gracilis Zone as the base of the global Upper Ordovician Series: Three potential stratotypes. In Proceedings 6th International Graptolite Conference (GWG-IPA) \& 1998 Field Meeting. IUGS Subcommission on Silurian Stratigraphy, 148-151.

Bergström, S.M., Chen, X. \& Wang, Z.-H. 1999. The Dawangou section, Tarim Basin (Xinjiang Autonomous Region), China: Potential as global stratotype for the base of the Nemagraptus gracilis Biozone and the base of the global Upper Ordovician Series. Acta Universitatis Carolinae-Geologica, 43: 69-71.

Bergström, S.M., Finney, S.C., Chen, X., Palsson, C., Wang, Z.-H. \& Grahn, Y. 2000. A proposed global boundary stratotype for the base of the Upper Series of the Ordovician System: the Fagelsang section, Scania, southern Sweden. Episodes, 23: 102-109.

Bergström, S.M., Chen, X., Gutiérrez-Marco, J.C. \& Dronov, A. 2009 The new chronostratigraphic classification of the Ordovician System and its relations to major regional series and stages to $\delta^{13} \mathrm{C}$ chemostratigraphy. Lethaia, 42: 97-107.

Bergström, S.M., Finney, S.C., Chen, X., Goldman, D. \& Leslie, S.A 2006. Three new Ordovician global stage names. Lethaia, 39: 287-288.
Bettley, R.M., Fortey, R.A. \& Siveter, D.J. 2001. High resolution correlation of Anglo-Welsh Middle to Upper Ordovician sequences and its relevance to international chronostratigraphy. Journal of the Geological Society, London, 158: 937-952.

Chen, X., Goldman, D., Leslie, S.A. \& Williams, N.A. 2008. New graptolite and conodont faunal data from the Middle Ordovician Dawangou section, Tarim Basin, Western Xinjiang, China, and its implication for biogeography. Geological Society of America Abstracts with Programs, 40: 85.

Cocks, L.R.M. \& Torsvik, T.H. 2002. Earth geography from 500 to 400 million years ago: A faunal and palaeomagnetic review. Journal of the Geological Society, London, 159: 631-644.

Dameng, L., Jianqi, T. \& Kuili, J. 2003. Organic petrology of potential source rocks in the Tarim Basin, NW China. Journal of Petroleum Geology, 26: 105-124.

Eisenack, A. 1931. Neue Mikrofossilien des baltischen Silurs. I. Palaeontologische Zeitschrift, 13: 74-118.

Eisenack, A. 1937. Neue Mikrofossilien des baltischen Silurs. IV. Palaeontologische Zeitschrift, 19: 217-243.

Eisenack, A. 1939. Chitinozoen und Hystrichosphaerideen im Ordovicium des Rheinischen Schiefergebirges. Senckenbergiana lethaea, 21(1): 135-152.

Eisenack, A. 1955. Neue Chitinozoen aus dem Silur des Baltikums und dem Devon der Eifel. Senckenbergiana lethaea, 36: 311-319.

Eisenack, A. 1962. Neotypen baltischer Silur-Chitinozoen und neue Arten. Neues Jahrbuch für Geologie und Paläontologie. Abhandlungen, 114: 291-316.

Eisenack, A. 1965. Die Mikrofauna der Ostseekalke. 1. Chitinozoen, Hystrichosphären. Neues Jahrbuch für Geologie und Paläontologie. Abhandlungen, 123: 115-148.

Eisenack, A. 1972. Beiträge zur Chitinozoen-Forschung. Palaeontographica A, 140, 117-130.

Finney, S.C. \& Bergström, S.M. 1986. Biostratigraphy of the Ordovician Nemagraptus gracilis zone. In: Hughes, C.P. \& Rickards, R.B. (Eds), Palaeoecology and biostratigraphy of Graptolites. Geological Society, London, 47-59.

Fortey, R.A., Harper, D.A.T., Ingham, J.K., Owen, A.W. \& Rushton, A.W.A. 1995. A revision of Ordovician series and stages from the historical type area. Geological Magazine, 132: 15-30.

Geng, L.Y., Wang, Y., Cai, X.Y. \& Tang, P. 2000. Chitinozoan biostratigraphy in China. In: Song, Z. (Ed.), Palynofloras and Palynomorphs of China. Press of University of Science and Technology of China, Hefei, 209-241.

Gradstein, F.M., Ogg, J.G., Smith, A.G., Bleeker, W. \& Lourens, L.J. 2004. A new Geologic Time Scale, with special reference to Precambrian and Neogene. Episodes, 27: 83-100.

Grahn, Y. 1981a. Middle Ordovician Chitinozoa from Öland. Sveriges Geologiska Undersökning, 784: 1-51.

Grahn, Y. 1981b. Ordovician Chitinozoa from the Stora Åsbotorp boring in Västergötland, south-central Sweden. Sveriges Geologiska Undersökning, 787: 1-40.

Grahn, Y. 1982. Caradocian and Ashgillian Chitinozoa from the subsurface of Gotland. Sveriges Geologiska Undersökning, 788: 1-66.

Grahn, Y., Nõlvak, J. \& Paris, F. 1996. Precise chitinozoan dating of Ordovician impact events in Baltoscandia. Journal of Micropalaeontology, 15: 21-35.

Jansonius, J. 1964. Morphology and classification of some Chitinozoa. Bulletin of Canadian Petroleum Geology, 12: 901-918.

Jenkins, W.A.M. 1967. Ordovician Chitinozoa from Shropshire. Palaeontology, 10: 436-488.

Jenkins, W.A.M. 1969. Chitinozoa from the Ordovician Viola and Fernvale Limestones of the Arbuckle Mountains, Oklahoma. Special Papers in Palaeontology, 5: 1-44.

Jinggui, L., Philp, P., Zifanga, M. et al. 2005. Aromatic compounds in crude oils and source rocks and their application to oil-source rock correlations in the Tarim basin, NW China. Journal of Asian Earth Sciences, 25: 251-268.

Li, J., Wicander, R., Yan, K. \& Zhu, H. 2006. An Upper Ordovician acritarch and prasinophyte assemblage from Dawangou, Xinjiang, northwestern China: Biostratigraphic and paleogeographic implications. Review of Palaeobotany and Palynology, 139: 97-128. 
Männil, R. 1986. Stratigraphy of kuckersite-bearing deposits C1b-C3. In: Puura, V. (Ed.), Geology of the Kuckersite-bearing beds of the Baltic oil shale basin. Academy of Sciences of the Estonian SSR, Institute of Geology, Tallinn, 12-24.

Miller, M.A. 1996. Chitinozoa. In: Jansonius, J. \& McGregor, D.C. (Eds), Palynology: principles and applications. Publishers Press, Salt Lake City, 1: $307-336$.

Neville, R.S.W. 1974. Ordovician Chitinozoa from western Newfoundland. Review of Palaeobotany and Palynology, 18: 187-221.

Nõlvak, J. \& Bauert, G. 2006. Distribution of Ordovician chitinozoans. In: Põldvere, A. (Ed.), Estonian Geological Sections. Bulletin 7. Kerguta (565) drill core. Geological Survey of Estonia, Tallin, 9-11.

Nõlvak, J. \& Grahn, Y. 1993. Ordovician chitinozoan zones from Baltoscandia. Review of Palaeobotany and Palynology, 79: 245-269.

Ottone, E.G., Holfeltz, G.D., Albanesi, G.L. \& Ortega, G. 2001. Chitinozoans from the Ordovician Los Azules formation, Central Precordillera, Argentina. Micropaleontology, 47(2): 97-110.

Paris, F. 1981. Les chitinozoaires dans le Paléozö̈que du sud-ouest de l'Europe (cadre géologique - étude systématique - biostratigraphie). Mémoire de la Société géologique et minéralogique de Bretagne, 26: 496pp.

Paris, F. 1990. The Ordovician chitinozoan biozones of the Northern Gondwana Domain. Review of Palaeobotany and Palynology, 66: 181-209.

Paris, F. 1996. Chitinozoan biostratigraphy and palaeoecology. In: Jansonius, J. \& McGregor, D.C. (Eds), Palynology: Principles and Applications. Publishers Press, Salt Lake City, 2: 531-552.

Paris, F. \& Verniers, J. 2005. Chitinozoa. In: Selley, R.C., Cocks, L.R.M. \& Plimer, I. (Eds), Encyclopedia of Geology. Elsevier, Amsterdam, 428-440.

Paris, F., Grahn, Y., Nestor, V. \& Lakova, I. 1999. A revised chitinozoan classification. Journal of Paleontology, 73: 549-570.

Tang, P., Geng, L.Y., Deng, S.H., Zhang, S.B., Paris, F. \& Zhu, H.C. 2007. Middle and Upper Ordovician chitinozoan assemblages from the Kuruktag area, northeastern Tarim Basin, China. Acta Palaeontologica Sinica, 46(Suppl.): 477-482.
Vandenbroucke, T.R.A. 2004. Chitinozoan biostratigraphy of the Upper Ordovician Fagelsang GSSP, Scania, southern Sweden. Review of Palaeobotany and Palynology, 130: 217-239.

Vandenbroucke, T.R.A. 2008a. Upper Ordovician chitinozoans from the historical type area in the UK. Monograph of the Palaeontographical Society, London, 161: 113pp.

Vandenbroucke, T.R.A. 2008b. An Upper Ordovician Chitinozoan Biozonation in British Avalonia (England \& Wales). Lethaia, 41: 275-294.

Vandenbroucke, T.R.A., Ancilletta, A., Fortey, R.A. \& Verniers, J. 2009. A modern assessment of Ordovician chitinozoans from the Shelve and Caradoc areas, Shropshire, and their significance for correlation. Geological Magazine, 146: 216-236.

Vandenbroucke, T.R.A., Armstrong, H., Williams, M. et al. 2010. Epipelagic chitinozoan biotopes map a steep latitudinal temperature gradient for earliest Late Ordovician seas: implications for a cooling Late Ordovician climate. Palaeogeography, Palaeoclimatology, Palaeoecology, DOI: 10.1016/j.palaeo.2009.11.026.

Wang, Q., Nishidai, T. \& Coward, M. 1992. The Tarim Basin, NW China; formation and aspects of petroleum geology. Journal of Petroleum Geology, 15: 5-34.

Webby, B.D., Cooper, R.A., Bergström, S.M. \& Paris, F. 2004. Stratigraphic framework and time slices. In: Webby, B.D., Droser, M.L., Paris, F. \& Percival, I. (Eds), The Great Ordovician Biodiversification Event. Columbia University Press, New York, 41-47.

Zhou, Z.Y. \& Chen, P.J. 1992. Biostratigraphy and Geological Evolution of Tarim. Science Press, Beijing, 416pp.

Zhou, Z.Y., Chen, X., Wang, Z.H. et al. 1992. Ordovician of Tarim. In: Zhou, Z.Y. \& Chen, P.J. (Eds), Biostratigraphy and Geological Evolution of Tarim. Science Press, Beijing, 62-13. 


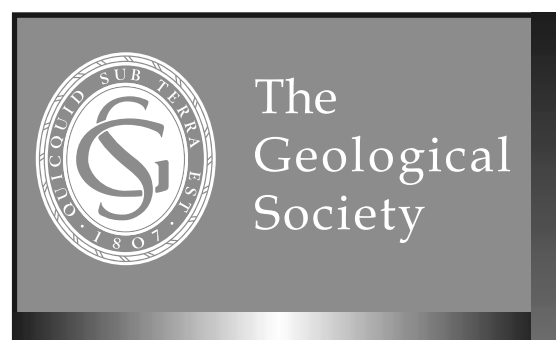

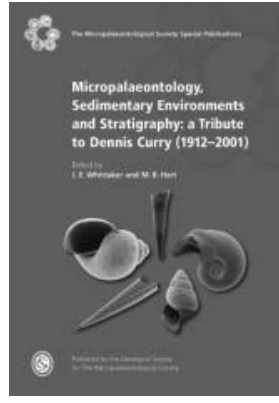

-ISBN: 978-1-86239-305-9

- September 2010

-304 pages

-Prices:

List: $\mathbf{f 9 0 . 0 0 / U S \$ 1 8 0 . 0 0}$

GSL: $£ 54.00 / U S \$ 108.00$

TMS: $\mathbf{f 4 5 . 0 0 / U S \$ 9 0 . 0 0}$

Online bookshop code:

TMS004
- The Micropalaeontological Society Series (TMS) Micropalaeontology, Sedimentary
Environments and Stratigraphy: A
Tribute to Dennis Curry (1912-2001)

\author{
Editors: J. E. Whittaker \& M. B. Hart
}

Dennis Curry was a remarkable polymath and philanthropist, leading a double-life as one of the UK's most gifted amateur geologists, whilst at the same time being an extremely successful businessman (as Managing Director of Currys Ltd). This Festschrift, authored by friends and specialists from Britain and France, pays tribute to his often seminal research as well as exhibiting the wide range of his geological interest. It contains 12 chapters and covers several differing aspects of micropalaeontology (pteropods, diatoms and especially foraminifera), Strontium Isotope Stratigraphy, Hampshire Basin stratigraphy and palaeogeography, as well as major contributions on English Channel sedimentology and the great faunal turnover affecting mammals at the Eocene-Oligocene boundary. A scientific appreciation of Dennis Curry, 'the professional amateur', with recollections of former colleagues at University College, London (where he was Visiting Professor), together with an assessment of the valuable collections he established and donated to The Natural History Museum, are also included. Copiously illustrated, this book is a must for all geologists.

Postage: UK: $+5 \%$ ( $£ 4.50$ minimum) Europe: $+15 \%$ ( $£ 9.00$ minimum) Rest of world: $+15 \%$ ( $£ 13.50$ minimum) All prices and postage valid until 31 December 2011. Please allow up to 28 days for delivery of in stock items in the UK. Parcels to Europe and Rest of World are sent by surface mail and can take 6 to 12 weeks to arrive. (Air or courier rates available on request).

Please order from: Geological Society Publishing House, Unit 7 Brassmill Enterprise Centre, Brassmill Lane, Bath BA1 3JN, UK Tel: +44 (0)1225 445046 Fax: +44 (0)1225 442836 Email: sales@geolsoc.org.uk Online bookshop: www.geolsoc.org.uk/bookshop Society Web Site: www.geolsoc.org.uk

For full details see the Online Bookshop: www.geolsoc.org.uk/bookshop
The Geological Society's Lyell Collection: journals, Special Publications and books online. For more information visit www.geolsoc.org.uk/LyellCollection 